This PDF is a selection from a published volume from the National Bureau of Economic Research

Volume Title: Preventing Currency Crises in Emerging Markets

Volume Author/Editor: Sebastian Edwards and Jeffrey A.

Frankel, editors

Volume Publisher: University of Chicago Press

Volume ISBN: 0-226-18494-3

Volume URL: http://www.nber.org/books/edwa02-2

Conference Date: January 2001

Publication Date: January 2002

Title: Does the Current Account Matter?

Author: Sebastian Edwards

URL: http://www.nber.org/chapters/c10633 


\title{
Does the Current Account Matter?
}

\author{
Sebastian Edwards
}

\subsection{Introduction}

The currency crises of the 1990s shocked investors, academics, international civil servants, and policy makers alike. Most analysts had missed the financial weaknesses in Mexico and East Asia, and when the crises erupted almost every observer was surprised by their intensity. ${ }^{1}$ This inability to predict major financial collapses is viewed as an embarrassment of sorts by the economics profession. As a result, during the last few years macroeconomists in academia, in the multilateral institutions, and in investment banks have been frantically developing crisis "early warning" models. These models have focused on a number of variables, including the level and currency composition of foreign debt, debt maturity, the weakness of the domestic financial sector, the country's fiscal position, its level of international reserves, political instability, and real exchange rate overvaluation, among others. Interestingly, different authors do not seem to agree on the role played by current account deficits in recent financial collapses. While some analysts have argued that large current account deficits have been behind major currency crashes, according to others the current account has not been overly important in many of these

Sebastian Edwards is the Henry Ford II Professor of International Business Economics at the Anderson Graduate School of Management at the University of California, Los Angeles (UCLA) and a research associate of the National Bureau of Economic Research.

The author thanks Alejandro Jara and Igal Magendzo for excellent assistance and benefited from discussions with Ed Leamer and James Boughton. The author is also grateful to Alejandro M. Werner and Jeffrey A. Frankel for helpful comments.

1. It should be noted that the crises in Russia (August 1998) and Brazil (January 1999) were widely anticipated. 
episodes. ${ }^{2}$ The view that current account deficits have played a limited role in recent financial debacles in the emerging nations is clearly presented by U.S. Treasury Secretary Larry Summers, who argued in his Richard T. Ely lecture that "[t]raditional macroeconomic variables, in the form of overly inflationary monetary policies, large fiscal deficits, or even large current account deficits, were present in several cases, but are not necessary antecedents to crisis in all episodes" (Summers 2000, 7, emphasis added).

The purpose of this paper is to investigate in detail the behavior of the current account in emerging economies, and in particular its role-if anyin financial crises. Models of current account behavior are reviewed, and a dynamic model of current account sustainability is developed. The empirical analysis is based on a massive data set that covers over 120 countries during more than twenty-five years. Important controversies related to the current account-including the extent to which current account deficits crowd out domestic saving - are also analyzed. Throughout the paper I am interested in whether there is evidence to support the idea that there are costs involved in running "very large" deficits. Moreover, I investigate the nature of these potential costs, including whether they are particularly high in the presence of other types of imbalances.

The rest of the paper is organized as follows: In section $1.2 \mathrm{I}$ review the way in which economists' views on the current account have evolved in the last twenty-five years or so. The discussion deals with academic as well as policy perspectives and includes a review of evolving theoretical models of current account behavior. The analysis presented in this section shows that there have been important changes in economists' views on the subject, from "deficits matter" to "deficits are irrelevant if the public sector is in equilibrium," back to "deficits matter," to the current dominant view that "current deficits may matter." In this section I argue that "equilibrium" models of frictionless economies are of little help in understanding actual current account behavior or assessing a country's degree of vulnerability. In section 1.3 I focus on models of the current account sustainability that have recently become popular in financial institutions, both private and official. More specifically, I argue that although these models provide some useful information about the long-run sustainability of the external sector accounts, they are of limited use in determining if, at a particular moment in time, a country's current account deficit is “too large." In order to illustrate this point, I develop a simple model of current account behavior that emphasizes the role of stock adjustments. In section $1.4 \mathrm{I}$ use a massive data set to analyze some of the most important aspects of current account behavior

2. For discussions on the causes behind the crises see, for example, Corsetti, Pesenti, and Roubini (1998), Sachs, Tornell, and Velasco (1996), the essays in Dornbusch (2000), and Edwards (1999). 
in the world economy during the last quarter century. The discussion deals with the following issues: (a) the distribution of current account deficits across countries and regions; (b) the relationship between current account deficits, domestic saving, and investment; (c) the effects of capital account liberalization on capital controls on the current account; and (d) the circumstances surrounding major current account reversals. I investigate, in particular, how frequent and how costly these reversals have been. In section $1.5 \mathrm{I}$ deal with the relationship between current account deficits and financial crises. I review the existing evidence and present some new results. Finally, section 1.6 contains some concluding remarks.

\subsection{Evolving Views on the Current Account: Models and Policy Implications}

In this section I analyze the evolving view on current account deficits, focusing on theoretical models as well as policy analyses. I show that economists' views have changed in important ways during the last twenty-five years, and I argue that many of these changes have been the result of important crisis situations in both the advanced and the emerging nations.

\subsubsection{The Early Emphasis on Flows}

In the immediate post-World War II period, most discussions on a country's external balance were based on the elasticities approach and focused on flows behavior. Even authors who fully understood that the current account is equal to income minus expenditure - including Meade (1951), Harberger (1950), Laursen and Metzler (1950), Machlup (1943), and Johnson (1955) - tended to emphasize the relation between relative price changes and trade flows. ${ }^{3}$

This emphasis on elasticities and the balance of trade also affected policy discussions in the developing nations. Indeed, until the mid-1970s, policy debates in the less developed countries were dominated by the so-called "elasticities pessimism" view, and most authors focused on whether a devaluation would result in an improvement in the country's external position, including its trade and current account balances. Cooper's (1971a, b) influential work on devaluation crisis in the developing nations is a good example of this emphasis. In these papers Cooper analyzed the consequences of twenty-one major devaluations in the developing world in the 1958-69 period, focusing on the effect of these exchange rate adjustments on the real exchange rate and on the balance of trade. Cooper (1971a) argued that although the relevant elasticities were indeed small, devaluations had, overall, been successful in helping to improve the trade and current account balances in the countries in his sample. In an extension of Cooper's work, 
Kamin (1988) confirmed the results that, historically, (large) devaluations tended to improve developing countries' trade balance.

Authors in the structuralist tradition argued that in the developing nations trade and current account imbalances were "structural" in nature and severely constrained poorer countries' ability to grow. According to this view, however, the solution was not to adjust the country's peg, but to encourage industrialization through import substitution policies. In Latin America this view was persuasively articulated by Raul Prebisch, the charismatic executive secretary of the U.N. Economic Commission for Latin America; in Asia it found its most respected defender in Professor Mahalanobis, the father of planning and the architect of India's Second Five Year Plan; and in Africa it was made the official policy stance with the Lagos Plan of Action of 1980.

\subsubsection{The Current Account as an Intertemporal Phenomenon: \\ The Lawson Doctrine and the 1980s Debt Crisis}

During the second part of the 1970s, and partially as a result of the oil price shocks, most countries in the world experienced large swings in their current account balances. These developments generated significant concern among policy makers and analysts and prompted a number of experts to analyze carefully the determinants of the current account. Perhaps the most important analytical development during this period was a move away from trade flows and a renewed and formal emphasis on the intertemporal dimensions of the current account. The departing point was, of course, very simple and was based on the recognition of two interrelated facts. First, from a basic national accounting perspective, the current account is equal to saving minus investment. Second, since both saving and investment decisions are based on intertemporal factors - such as life cycle considerations and expected returns on investment projects - the current account is necessarily an intertemporal phenomenon. Sachs (1981) forcefully emphasized the intertemporal nature of the current account, arguing that, to the extent that higher current account deficits reflected new investment opportunities, there was no reason to be concerned about them.

\section{Theoretical Issues}

Obstfeld and Rogoff (1996) have provided a comprehensive review of modern models of the current account that assume intertemporal optimization on behalf of consumers and firms. In this type of model, consumption smoothing across periods is one of the fundamental drivers of the current account. The most powerful insight of the modern approach to the current account can be expressed in a remarkably simple equation. Assuming a constant world interest rate, equality between the world discount factor $[1 /(1+r)]$ and the representative consumer's subjective discount factor 
$\beta$, and no borrowing constraints, the current account deficit (CAD) can be written as ${ }^{4}$

$$
\mathrm{CAD}_{t}=\left(Y_{t}^{*}-Y_{t}\right)-\left(I_{t}^{*}-I_{t}\right)-\left(G_{t}-G t^{*}\right),
$$

where $Y_{t}, I_{t}$, and $G_{t}$ are current output, consumption, and government spending, respectively. $Y_{t}^{*}, I_{t}^{*}$, and $G_{t}^{*}$, on the other hand, are the "permanent" levels of these variables. The permanent value of $Y\left(Y_{t}^{*}\right)$ is defined as

$$
Y_{t}^{*}=\frac{r}{1+r} \sum_{j=t}\left(\frac{r}{1+r}\right)^{j-t} Y_{j} .
$$

The sum runs from $j=t$ to infinity. That is, equation (2) defines the permanent value of $Y$ as the annuity value computed at the constant interest rate $r$. The definitions of $I_{t}^{*}$ and $G_{t}^{*}$ are exactly equivalent to that of $Y_{t}^{*}$ in equation (2).

According to equation (1), if output falls below its permanent value, $\left(Y_{t}^{*}\right.$ $\left.-Y_{t}\right)>0$, there will be a higher current account deficit. Similarly, if investment increases above its permanent value, there will be a higher current account deficit. The reason for this is that new investment projects will be partially financed with an increase in foreign borrowing, thus generating a higher current account deficit. Likewise, an increase in government consumption above $G t^{*}$ will result in a higher current account deficit. Although equation (1) is very simple, it captures the fundamental insights of modern current account analysis. Moreover, extensions of the model, including the relaxation of the assumption that the subjective discount factor is equal to the world discount factor, do not alter its most important implications. If, however, the constant world interest rate assumption is relaxed, the analysis becomes somewhat more complicated. In this case, the current account deficit will be fundamentally affected by the country's net foreign assets position and by the relationship between the world interest rate and its "permanent" value, $r_{t}^{*}$. With a variable world interest rate, equation (1) becomes

$$
\mathrm{CAD}_{t}=\left(Y_{t}^{*}-Y_{t}\right)-\left(I_{t}^{*}-I_{t}\right)-\left(G_{t}-G_{t}^{*}\right)-\left(r_{t}^{*}-r_{t}\right) B_{t}-\xi_{t},
$$

where $B_{t}$ is the country's net foreign asset position. If the residents of this country are net holders of foreign assets, $B_{t}>0$ (see Obstfeld and Rogoff 1996). The consumption adjustment factor, $\xi_{t}$, arises from the fact that the world discount factor is not any longer equal to the consumers' subjective discount factor. Notice that under most plausible parameter values $\xi_{t}$ is rather small (Obstfeld and Rogoff 1996). An important implication of equation (3) says that if the country is a net foreign debtor $\left(B_{t}<0\right)$ and the world interest rate exceeds its permanent level, the current account deficit will be higher.

4. Obstfeld and Rogoff (1996, 74). For models that generate similar expressions see, for example, Razin and Svensson (1983), Frenkel and Razin (1987), and Edwards (1989). 
A number of versions of optimizing models of the current account have appeared in the literature published since 1980. Razin and Svensson (1983), for example, built an optimizing framework to explore the validity of the Laursen-Metzler-Harberger condition developed in the 1950s and concluded that the insights from these early models were largely valid in a fully optimizing, two period, general equilibrium model. Edwards and van Wijnbergen (1986) explored the current account implications of alternative speeds of trade liberalization. They found out that in a framework in which the country in question faced a borrowing constraint, a gradual liberalization of trade was preferred to a cold-turkey approach. Frenkel and Razin (1987) analyzed the way in which alternative fiscal policies affected the current account balance through time. Edwards (1989) introduced nontradable goods in an effort to understand the connection between the real exchange rate and the current account through time. Sheffrin and Woo (1990) used an annuity framework to develop a number of specific testable hypotheses from the intertemporal framework. Ghosh and Ostry (1995) tested the intertemporal model using data for a group of developing countries. They argue that, overall, their results adequately capture the most important features of modern optimizing models of the current account.

Numerical simulations based on the intertemporal approach sketched above suggest that a country's optimal response to negative exogenous shocks is to run very high current account deficits. These large deficits are, of course, the mechanism through which the country nationals smooth consumption. An important consequence of this models' result is that a small country can accumulate a very large external debt and will have to run a sizeable trade surplus in the steady state in order to repay it. The problem, however, is that the external accounts and the external debt ratios implied by these models are not observed in reality. Obstfeld and Rogoff (1996), for example, develop a model of a small open economy with Ak technology and a constant rate of productivity growth that exceeds world productivity growth. ${ }^{5}$ This economy faces a constant world interest rate $r$ and no borrowing constraint. Under a set of plausible parameters, the steady-state trade surplus is equal to 45 percent of gross domestic product (GDP), and the steady-state ratio of debt to GDP is equal to $15 .{ }^{6}$ Needless to say, neither of these figures has been observed in modern economies (on actual distributions of the current account see the discussion in section 1.4 of this paper). Fernandez de Cordoba and Kehoe (2000) developed an intertemporal model of a small economy to analyze the effects of lifting capital controls on the dynamics of the current account. The basic version of their model assumes both tradable and nontradable goods, physical capital, and interna-

5. "Small" means that the cost of borrowing does not rise with the quantity.

6. Obstfeld and Rogoff (1996) do not claim that this model is particularly realistic. In fact, they present its implications to highlight some of the shortcomings of simple intertemporal models of the current account. 
tionally traded bonds, and no borrowing constraint. An important feature of the model - and one that sets it apart from that of Obstfeld and Rogoff (1996) discussed above - is that the rate of technological progress is equal to that of the rest of the world. The authors calibrate the model for the case of Spain and find that the optimal response to a financial reform is to run a current account deficit that peaks at 60 percent of GDP. ${ }^{7}$ As the authors themselves acknowledge, this figure tends to contradict strongly what is observed in reality. Following the financial liberalization reform, Spain's current account deficit peaked at 3.4 percent of GDP.

The fact that these models predict optimal levels of the current account deficit that are an order of magnitude higher than those observed in the real world poses an important challenge for economists. A number of authors have tried to deal with these disturbing results by introducing adjustment costs and other type of rigidities into the analysis. Blanchard (1983), for example, developed a current account model with investment installation costs to investigate the dynamics of debt and the current account in a small developing economy, such as that of Brazil. A simulation of this model for feasible parameter values indicated that a country with Brazil's characteristics should accumulate foreign debt in excess of 300 percent of its gross national product (GNP). Moreover, according to this model, in the steady state the country in question should run a trade surplus equal to 10 percent of GDP. Although these numbers are not as extreme as those obtained from simple models without rigidities, they are quite implausible and are not usually observed in the real world. Fernandez de Cordoba and Kehoe (2000) introduced a series of extensions to their basic model in an effort to generate more plausible simulation results. They showed that it was not possible to improve the results by simply imposing a greater degree of curvature into the production possibility frontier. They also show that by assuming costly and slow factor mobility across sectors they could generate current account deficits in their simulation exercises that were more modest, although still very high from a historical perspective. More recently, a number of authors have developed models with borrowing constraints in an effort to generate current account paths that are closer to reality.

\section{Policy Interpretations of the Intertemporal Approach}

An important policy implication of the intertemporal perspective is that policy actions that result in higher investment opportunities will necessarily generate a deterioration in the country's current account. According to this view, however, this type of worsening of the current account balance should not be a cause for concern or for policy action. This reasoning led Sachs $(1981,243)$ to argue that the rapid increase in the developing coun-

7. Their analysis is carried out in terms of the trade account balance. In this model there are no differences between the trade and current account balances. 
tries' foreign debt in the 1978-81 period was not a sign of increased vulnerability. It is interesting to quote Sachs extensively:

The manageability of the LDC debt has been the subject of a large literature in recent years. If my analysis is correct, much of the growth in LDC debt reflects increased in investment and should not pose a problem of repayment. The major borrowers have accumulated debt in the context of rising or stable, but not falling, saving rates. This is particularly true for Brazil and Mexico. ... (Sachs 1981, 243, emphasis added)

This view was also endorsed by Robischek (1981), one of the most senior and influential International Monetary Fund (IMF) officials during the 1970s and 1980s. Commenting on Chile's situation in 1981 - a time when the country's current account deficit surpassed 14 percent of GDP — he argued that, to the extent that the public sector accounts were under control and that domestic saving was increasing, there was absolutely no reason to worry about major current account deficits. As it turned out, however, shortly after Robischek expressed his views, Chile entered into a deep financial crisis that ended with a major devaluation, the bankruptcy of the banking sector, and a GDP decline of 14 percent (see Edwards and Edwards 1991). The argument that a large current account deficit is not a cause of concern if the fiscal accounts are balanced has been associated with former Chancellor of the Exchequer Nigel Lawson and has come to be known as Lawson's Doctrine.

The respected Australian economist Max Corden has possibly been the most articulate exponent of the intertemporal policy view of the current account. In the important article "Does the Current Account Matter?" Corden (1994) makes a distinction between the "old" and "new" views on the current account. According to the former, "a country can run a current account deficit for a limited period. But no positive deficit is sustainable indefinitely" (Corden 1994, 88). The "new" view, on the other hand, makes a distinction between deficits that are the result of fiscal imbalances and those that respond to private sector decisions. According to the new view, "an increase in the current account deficit that results from a shift in private sector behavior - a rise in investment or a fall in savings-should not be a matter of concern at all" (Corden 1994, 92, emphasis added).

The eruption of the debt crisis in 1982 suggested that some of the more important policy implications of the new (intertemporal) view of the current account were subject to important flaws. Indeed, some of the countries affected by this crisis had run very large current account deficits in the presence of increasing investment rates or balanced fiscal accounts. In that regard, the case of Latin America is quite interesting. With the exception of oil producer Venezuela, current account deficits skyrocketed in 1981. This was the case in countries with increasing investment, such as Brazil and Mexico, as well as in countries with a balanced fiscal sector and rising investment, such as Chile. 


\subsubsection{Views on the Current Account in the Post-1982 Debt Crisis Period}

In light of the debt crisis of 1982, a number of authors explicitly moved away from the implications of the Lawson Doctrine and argued that large current account deficits were often a sign of trouble to come, even if domestic savings were high and increasing. Fischer (1988) made this point forcefully in an article on real exchange rate overvaluation and currency crises: "The primary indicator [of a looming crisis] is the current account deficit. Large actual or projected current account deficits - or, for countries that have to make heavy debt repayments, insufficiently large surplusesare a call for devaluation" (115). An important point raised by Fischer was that what matters is not whether there is a large deficit, but whether the country in question is running an "unsustainable" deficit. In his words, "if the current account deficit is 'unsustainable' ... or if reasonable forecasts show that it will be unsustainable in the future, devaluation will be necessary sooner or later" (115). In the aftermath of the 1990s crises, (as will be discussed in section 1.3 of this paper) the issue of current account sustainability moved decisively to the center of the policy debate. In the years immediately following the 1982 debt crisis, Cline (1988) also emphasized the importance of current account deficits, as did Kamin (1988), whose extensive empirical work suggested that the trade and current accounts "deteriorated steadily through the year immediately prior to devaluation" (14). In their analysis of the Chilean crisis of 1982, Edwards and Edwards (1991) argued that Chile's experience-in which a 14 percent current account deficit was generated by private-sector-induced capital inflows - showed that the Lawson Doctrine was seriously flawed.

\subsubsection{The Surge of Capital Inflows in the 1990s, the Current Account, and the Mexican Crisis}

During much of the 1980s the majority of the developing countries were cut off from the international capital markets, and either ran current account surpluses or small deficits. This was even the case for the so-called East Asian Tigers, which had not been affected by the debt crisis. Indeed, between 1982 and 1990 Hong Kong, Korea, and Singapore posted current account surpluses, while Indonesia, Malaysia, the Philippines, and Thailand ran moderate deficits. Indonesia's and Thailand's deficits were the highest in the group, averaging 3.2 percent of GDP.

Starting in 1990, however, a large number of emerging countries were able once again to attract private capital. This was particularly the case in Latin America, where by 1992 the net volume of funds had become so large-exceeding 35 percent of the region's exports - that a number of analysts began to talk about Latin America's "capital inflows problem" (Calvo, Leiderman, and Reinhart 1993; Edwards 1993). Naturally, the counterpart of these large capital inflows was a significant widening in capital account 
deficits as well as a rapid accumulation of international reserves. During the first half of the 1990s, and in the midst of international capital abundance, there was a resurgence of Lawson's Doctrine in some policy circles. This was particularly the case in analyses of the evolution of the Mexican economy during the years preceding the peso crisis of 1994-95. In 1990 the international financial markets rediscovered Mexico, and large amounts of capital began flowing into the country. As a result, Mexico could finance significant current account deficits - in 1992-94 they averaged almost 7 percent of GDP. When some analysts pointed out that these deficits were very large, the Mexican authorities responded by arguing that, since the fiscal accounts were under control, there was no reason to worry. In 1993 the Bank of Mexico maintained that "the current account deficit has been determined exclusively by the private sector's decisions. . . . Because of the above and the solid position of public finances, the current account deficit should clearly not be a cause for undue concern" (179-80, emphasis added). In his recently published memoirs, former President Carlos Salinas de Gortari (2000) argues that the very large current account deficit was not a cause of the December 1994 crisis. According to him, two of the most influential cabinet members-Secretary of Commerce Jaime Serra and Secretary of Programming, and future president, Ernesto Zedillo - pointed out in the early 1990s that, since the public sector was in equilibrium, Mexico's large current account deficit was harmless. ${ }^{8}$

Not everyone, however, agreed with this position. In the 1994 Brookings Panel session on Mexico, Stanley Fischer argued that

[t]he Mexican current account deficit is huge, and it is being financed largely by portfolio investment. Those investments can turn around very quickly and leave Mexico with no choice but to devalue ... [a]nd as the European and especially the Swedish experiences show, there may be no interest rate high enough to prevent an outflow and a forced devaluation. $(1994,306)$

The World Bank staff expressed concern about the widening current account deficit. In Trends in Developing Economies 1993, the Bank staff wrote: "In 1992 about two-thirds of the widening of the current account deficit can be ascribed to lower private savings. . . . If this trend continues, it could renew fears about Mexico's inability to generate enough foreign exchange to service debt" (World Bank 1993, 330).

\subsubsection{Views on the Current Account in the Post-1990s Currency Crashes}

In the aftermath of the Mexican crisis of 1994, a large number of analysts maintained, once again, that Lawson's Doctrine was seriously flawed. In an address to the Board of Governors of the Interamerican Development 
Bank, Lawrence Summers (1996), then the U.S. deputy secretary of the treasury, was extremely explicit when he said, "current account deficits cannot be assumed to be benign because the private sector generated them" (46). This position was also taken by the IMF in postmortems of the Mexican debacle. In evaluating the role of the fund during the Mexican crisis, the director of the Western Hemisphere department and the chief of the Mexico division wrote: "[L]arge current account deficits, regardless of the factors underlying them[,] are likely to be unsustainable (Loser and Williams 1997, 268). According to Secretary Summers, "close attention should be paid to any current account deficit in excess of 5 percent of GDP, particularly if it is financed in a way that could lead to rapid reversals."

Whether "large" current account deficits were in fact a central cause of the East Asian debacle continues to be a somewhat controversial issue. Using the available evidence, in a recent comprehensive study Corsetti, Pesenti, and Roubini (1998) analyze the period leading to the East Asian crisis and argue that there is some support for the position that large current account deficits were one of the principal factors behind the crisis. According to them, "as a group, the countries that came under attack in 1997 appear to have been those with large current account deficits throughout the 1990s" (7, emphasis in the original). They then add in a rather guarded way, "prima facie evidence suggests that current account problems may have played a role in the dynamics of the Asian meltdown" (8). Radelet and Sachs (2000) have also argued that large current account deficits were an important factor leading to the crisis. Additionally, commenting on the eruption of the crisis in Thailand, the Chase Manhattan Bank (1997) argued that large current account deficits had been a basic cause of the crises. A close analysis of the data shows, however, that with the exceptions of Malaysia and Thailand the current account deficits were not very large. Take, for instance, the 1990-96 period: for the five East Asia crisis countries, the deficit exceeded the arbitrary 5 percent threshold only twelve out of thirty-five possible times. The frequency of occurrence is even lower for the two years preceding the crisis, at three out of ten possible times (Edwards 1999).

In view of the (perceived) limited importance of the current account, many authors have developed crisis models in which the current account deficit is not central. In Calvo (2000), for example, a currency crisis responds to financial fragilities in the country in question and is independent of the current account. A particularly important fragility is the mismatch between the maturity of banks' assets and obligations. Chang and Velasco (2000) have developed a series of models in which a crisis is the result of self-fulfilling expectations. A somewhat different line of research has emphasized the role of borrowing constraints. In this setting, the nationals of the country in question cannot borrow as much as they wish from the international financial market; an upward-sloping supply for foreign funds limits their ability to smooth consumption. An appealing feature of this 
type of model is that the optimal current account deficit does not take the implausible values generated by the small country models discussed above. Moreover, in borrowing constraints models, changes in the level of the borrowing constraint - generated by changes in the lender's expectations, for example - can indeed result in currency crises. A good example is Atkeson and Rios-Rull's (1996) model of a credit-constrained country. In this setting, current account problems may arise even if fiscal and monetary policies are consistent; a change in investors' perceptions is all that is necessary.

An important consequence of the 1990s currency crashes was that market participants, and in particular private investors, became concerned with the evolution of emerging nations' current account balances. This concern has been translated into formal efforts to develop models of current account "sustainability." The issue at hand has been succinctly put by MilesiFerretti and Razin (1996): "What persistent level of current account deficits should be considered sustainable? Conventional wisdom is that current account deficits above 5\% of GDP flash a red light, in particular if the deficit is financed with short-term debt."

\subsection{How Useful are Models of Current Account Sustainability?}

As mentioned in the preceding section, in the aftermath of the Mexican crisis many analysts argued that the so-called "new" view of the current account, based on Lawson's Doctrine, was seriously flawed. While some, such as Bruno (1995), argued that large deficits stemming from higher investment (as in East Asia) were not particularly dangerous, others maintained that any deficit in excess of a certain threshold - say, 4 percent of GDP was a cause for concern. Partially motivated by this debate, Milesi-Ferretti and Razin (1996) developed a framework to analyze current account sustainability. Their main point was that the "sustainable" level of the current account was that level consistent with solvency. This, in turn, means the level at which "the ratio of external debt to GDP is stabilized" (MilesiFerretti and Razin 1998). Analyses of current account sustainability have become particularly popular among investment banks. For instance, Goldman Sachs's GS-SCAD model developed in 1997 has become popular among analysts interested in assessing emerging nations' vulnerability. More recently, Deutsche Bank (2000) has developed a model of current account sustainability both to analyze whether a particular country's current account is "out of line" and to evaluate the appropriateness of its real exchange rate.

The basic idea behind sustainability exercises is captured by the following simple analysis. As pointed out, solvency requires that the ratio of the (net) international demand for the country's liabilities (both debt and nondebt liabilities) stabilize at a level compatible with foreigners' net demand 
for these claims on future income flows. Under standard portfolio theory, the net international demand for country $j$ 's liabilities can be written as

$$
\delta_{j}=\alpha_{j}\left(W-W_{j}\right)-\left(1-\alpha_{j j}\right) W_{j},
$$

where $\alpha_{j}$ is the percentage of world's wealth $(W)$ that international investors are willing to hold in the form of country $j$ 's assets; $W_{j}$ is country $j$ 's wealth (broadly defined), and $\alpha_{i j}$ is country $j$ 's asset allocation on its own assets. The asset allocation shares $\alpha_{j}$ and $\alpha_{i j}$ depend, as in standard portfolio analyses, on expected returns and perceived risk. Assuming that country's $j$ wealth is a multiple $\lambda$ of its (potential or full employment) GDP, and that country's $j$ wealth is a fraction $\beta_{j}$ of world's wealth $W$, it is possible to write the (international) net demand for country's $j$ assets as ${ }^{9}$

$$
\delta_{j}=\left[\alpha_{j} \theta_{j}-\left(1-\alpha_{j j}\right)\right] \lambda_{j j} Y_{j},
$$

where $Y_{j}$ is (potential) GDP, and $\theta_{j}=\left(1-\beta_{j}\right) / \beta_{j}$. Denoting $\left\{\left[\alpha_{j} \theta_{j}-(1-\right.\right.$ $\left.\left.\left.\alpha_{j j}\right)\right] \lambda_{j j}\right\}=\gamma_{j}^{*}$, then,

$$
\delta_{j}=\gamma_{j}^{*} Y_{j}
$$

Equation (6) simply states that, in long-run equilibrium, the net international demand for country $j$ 's assets can be expressed as a proportion $\gamma_{j}^{*}$ of the country's (potential or sustainable) GDP. The determinants of the factor of proportionality are given by equation (3) and, as expressed, include relative returns and perceived risk of country $j$ and other countries. ${ }^{10}$

In this framework, and under the simplifying assumption that international reserves don't change, the "sustainable" current account ratio is given by ${ }^{11}$

$$
(C / Y)_{j}=\left(g_{j}+\pi_{j}^{*}\right)\left\{\left[\alpha_{j} \theta_{j}-\left(1-\alpha_{j j}\right)\right] \lambda_{j j}\right\},
$$

where $g_{j}$ is the country's sustainable rate of growth, and $\pi_{j}^{*}$ is a valuation factor (approximately) equal to international inflation. ${ }^{12}$ Notice that if $\left[\alpha_{j} \theta_{j}\right.$ $\left.-\left(1-\alpha_{i j}\right)\right]<0$, domestic residents' demand for foreign liabilities exceeds foreigners' demand for the country's liabilities. Under these circumstances, the country will have to run a current account surplus in order to maintain a stable (net external) liabilities-to-GDP ratio. Notice that according to equation (4) there is no reason for the "sustainable" current account deficit to be the same across countries. In fact, that would only happen by sheer coincidence. The main message of equation (4) is that "sustainable" current

9. This expression will hold for every period $t$; I have omitted the subscript $t$ in order to economize on notation.

10. The assumptions of constant $\lambda$ and $\theta$ are, of course, highly simplifying.

11. As a result of this assumption, equation (6) overstates (slightly) the "sustainable" current account ratio.

12. Under the restrictive assumption that international inflation is equal to zero, this expression corresponds exactly to Goldman Sachs's equation (8). See Ades and Kaune (1997, 6). 
Table 1.1 External World's Desired Holdings of a Country's Liabilities ( $\%$ of GDP)

\begin{tabular}{lc}
\hline Country & Desired Holding \\
\hline Argentina & 48.4 \\
Brazil & 38.3 \\
Bulgaria & 42.8 \\
Chile & 48.4 \\
China & 129.2 \\
Colombia & 38.3 \\
Czech Republic & 31.3 \\
Ecuador & 31.3 \\
Hungary & 31.3 \\
India & 47.2 \\
Indonesia & 53.9 \\
Korea & 55.4 \\
Malaysia & 53.9 \\
Mexico & 38.3 \\
Morocco & 31.9 \\
Panama & 38.3 \\
Peru & 48.4 \\
The Philippines & 57.1 \\
Poland & 55.4 \\
Romania & 38.3 \\
Russia & 38.3 \\
South Africa & 38.3 \\
Thailand & 64.6 \\
Turkey & 38.3 \\
Venezuela & 38.3 \\
\hline
\end{tabular}

Source: Goldman Sachs.

account balances vary across countries and depend on whatever variables affect portfolio decisions and economic growth. In other words, the notion that no country can run a sustainable deficit in excess of 4 or 5 percent of GDP, or any other arbitrary number, is nonsense.

Using a very similar framework to the one developed above, Goldman Sachs has made a serious effort to actually estimate long-run sustainable current account deficits for a number of countries (Ades and Kaune 1997). Using a twenty-five-country data set, Goldman Sachs estimated the ratio of external liabilities foreigners are willing to hold $-\gamma_{j}^{*}$ in the model sketched above - as well as each country's potential rate of growth. Table 1.1 contains Goldman Sachs's estimates of $\gamma_{j}^{*}$, while table 1.2 presents their estimates of long-run sustainable current account deficits. In addition to estimating these steady-state imbalances, Goldman Sachs calculated asymptotic convergence paths toward those long-run current accounts. These are presented in table 1.2 under short-run sustainable balances. Several interesting features emerge from these tables. First, there is a wide vari- 
Table 1.2 Sustainable Current Account Deficit (SCAD) (\% of GDP)

\begin{tabular}{lrrc}
\hline Country & 1997 CAD & SCAD & Steady-State SCAD \\
\hline Argentina & 2.7 & 3.9 & 2.9 \\
Brazil & 4.5 & 2.9 & 1.9 \\
Bulgaria & -2.6 & 0.4 & 2.4 \\
Chile & 3.7 & 4.2 & 2.9 \\
China & -1.4 & 12.9 & 11.1 \\
Colombia & 4.8 & 2.6 & 1.9 \\
Czech Republic & 8.6 & 2.1 & 1.3 \\
Ecuador & 2.0 & -0.5 & 1.3 \\
Hungary & 4.0 & 0.8 & 1.3 \\
India & 1.8 & 3.8 & 2.8 \\
Indonesia & 3.0 & 4.0 & 3.4 \\
Korea & 3.8 & 4.9 & 3.6 \\
Malaysia & 4.1 & 4.9 & 3.4 \\
Mexico & 1.7 & 2.1 & 1.9 \\
Morocco & 1.8 & 0.3 & 1.3 \\
Panama & 6.1 & 0.8 & 1.9 \\
Peru & 5.1 & 3.3 & 2.9 \\
The Philippines & 4.2 & 4.5 & 3.8 \\
Poland & 3.8 & 4.7 & 3.6 \\
Romania & 0.5 & 2.3 & 1.9 \\
Russia & -2.8 & 2.5 & 1.9 \\
South Africa & 1.8 & 3.0 & 1.9 \\
Thailand & 5.4 & 6.0 & 4.5 \\
Turkey & 1.2 & 2.1 & 1.9 \\
Venezuela & -4.6 & 2.2 & 1.9 \\
\hline Sorce: & & &
\end{tabular}

Source: Goldman Sachs.

ety of estimated long-run "sustainable" deficits. Second, with the notable exception of China-whose estimated "sustainable" deficit is an improbable 11 percent of GDP - the estimated levels are very modest, ranging from 1.9 to 4.5 percent of GDP. Third, although the range for the short-run sustainable level is broader, in very few countries does it exceed 4 percent of GDP. Fourth, the estimates of the ratio of the external liabilities foreigners are willing to hold for each country $-\gamma_{j}^{*}$ in the model sketched above - exhibit more variability. Here the range (excluding China) goes from 31.5 to 64.6 percent of GDP.

Although this type of analysis represents an improvement with respect to arbitrary current account thresholds, it is subject to a number of serious limitations, including the fact that it is exceedingly difficult to obtain reliable estimates for the key variables. In particular, there is very little evidence on equilibrium portfolio shares. Also, the underlying models used for calculating the long-run growth tend to be very simplistic.

The most serious limitation of this framework, however, is that it does not take into account, in a satisfactory way, transitional issues arising from 
changes in portfolio allocations. These can have a fundamental effect on the way in which the economy adjusts to changes in the external environment. For example, the speed at which a country absorbs surges in foreigners' demand for its liabilities will have an effect on the sustainable path of the current account (Bacchetta and van Wincoop 2000).

The key point is that even small changes in foreigners' net demand for the country's liabilities may generate complex equilibrium adjustment paths for the current account. These current account movements will be necessary for the new portfolio allocation to materialize and will not generate a disequilibrium, or unsustainable balance. However, when this equilibrium path of the current account is contrasted with threshold levels obtained from models, such as the one sketched above, analysts could (incorrectly) conclude that the country is facing a serious disequilibrium.

In order to illustrate this point, assume that equation (8) captures the way in which the current account responds to change in portfolio allocations. In this equation, $\gamma_{t}^{*}$ is the new desired level (relative to GDP) of foreigners' (net) desired holdings of the country's liabilities; $\gamma_{t-1}^{*}$, on the other hand, is the old desired level.

$$
(C / Y)_{t}=\left(g+\pi^{*}\right) \gamma_{t}^{*}+\beta\left(\gamma_{t}^{*}-\gamma_{t-1}^{*}\right)-\eta\left[(C / Y)_{t-1}-\left(g+\pi^{*}\right) \gamma_{t}^{*}\right],
$$

where, as before, $\gamma^{*}=\left\{\left[\alpha_{j} \theta_{j}-\left(1-\alpha_{j j}\right)\right] \lambda_{j j}\right\}$. According to this equation, short-term deviations of the current account from its long-run level can result from two forces. The first is a traditional stock adjustment term, $\left(\gamma_{t}^{*}-\right.$ $\left.\gamma_{t-1}^{*}\right)$, that captures deviations between the demanded and the actual stock of assets. If $\gamma_{t}^{*}>\gamma_{t-1}^{*}$, then the current account deficit will exceed its long-run value. The speed of adjustment, $\beta$, will depend on a number of factors, including the degree of capital mobility in the country in question and the maturity of its foreign debt. The second force, which is captured by $-\eta\left[(C / Y)_{t-1}\right.$ $\left.-\left(g+\pi^{*}\right) \gamma_{t}^{*}\right]$ in equation (7), is a self-correcting term. This term plays the role of making sure that in this economy there is some form of "consumption smoothing." The importance of this self-correcting term will depend on the value of $\eta$. If $\eta=0$, the self-correcting term will play no role, and the dynamics of the current account will be given by a more traditional stock adjustment equation. In the more general case, however, when both $\beta$ and $\eta$ are different from zero, the dynamics of the current account will be richer, and discrepancies between $\gamma_{t}^{*}$ and $\gamma_{t-1}^{*}$ will be resolved gradually through time.

As may be seen from equation (8), in the long-run steady state, when $\left(\gamma_{t}^{*}\right.$ $\left.=\gamma_{t-1}^{*}\right)$ and $(C Y)_{t-1}=C / Y$, the current account will be at its sustainable level, $\left(g+\pi^{*}\right)\left\{\left[\alpha_{j} \theta_{j}-\left(1-\alpha_{j j}\right)\right] \lambda_{j j}\right\}$. The dynamic behavior for the net stock of the country's assets in the hands of foreigners, as a percentage of GDP, will be given by equation (9).

$$
\gamma_{t}=\frac{\gamma_{t-1}+(C / Y)_{t}}{1+g+\pi^{*}}
$$


The implications of incorporating the adjustment process can be illustrated with a simple example based on the Goldman Sachs computations presented above. Notice that according to the figures in table 1.1, by the end of 1996 there was a significant gap between Goldman Sachs's estimates of foreigners' desired holdings of Mexican and Argentine liabilities: Although the Mexican ratio stood at 38.3 percent of the country's GDP, the corresponding figure for Argentina was 48.4 percent. Assume that for some reason-a reduction in perceived Mexican country risk, for example - this gap is closed to one-half of its initial level and that the demand for Mexican liabilities increases to 43 percent of Mexican GDP. Figure 1.1 presents the estimated evolution of the sustainable current account path under the assumptions that Mexican growth remains at 5 percent and that world inflation is zero-both assumptions made by Goldman Sachs. In addition, it is assumed that $\beta=0.65, \eta=0.45$, and that the increase in $\gamma^{*}$ is spread over three years.

The results from this simple exercise are quite interesting: First, as may be seen, the initial level of the sustainable current account level is equal to 1.9 percent of GDP, exactly the level estimated by Goldman Sachs (see table 1.2). Second, the current account converges to 2.15 percent of GDP, as suggested by equation (7). Third, and more important for the analysis in this section, the dynamic of the current account is characterized by a sizable overshooting, with the "equilibrium path" deficit peaking at 3.5 percent of GDP. If, on the other hand, it is assumed that the increase in $\gamma^{*}$ takes place in one period, the equilibrium deficit would peak at a level in excess of 5 percent, a figure twice as large as the new long-term sustainable level. What makes this exercise particularly interesting is that these rather large overshootings are the result of very small changes in portfolio preferences. This strongly suggests that in a world where desired portfolio shares are constantly changing, the concept of a sustainable equilibrium current account path is very difficult to estimate. Moreover, this simple exercise indicates that relying on current account ratios-even ratios calculated using current "sustainability" frameworks - can be highly misleading. These dynamic features of current account adjustment may explain why so many authors have failed to find a direct connection between current account deficits and crises.

The analysis presented above suggests two important dimensions of adjustment and crisis prevention. First, current account dynamics will affect real exchange rate behavior. More specifically, current account overshooting will be associated with a temporary real exchange rate appreciation. The actual magnitude of this appreciation will depend on a number of variables, including the income demand elasticity for nontradables and the labor intensity of the nontradable sector. In order for this dynamic adjustment to be smooth, the country should have the ability to implement the required real exchange rate depreciation in the second phase of the process. This is 
A

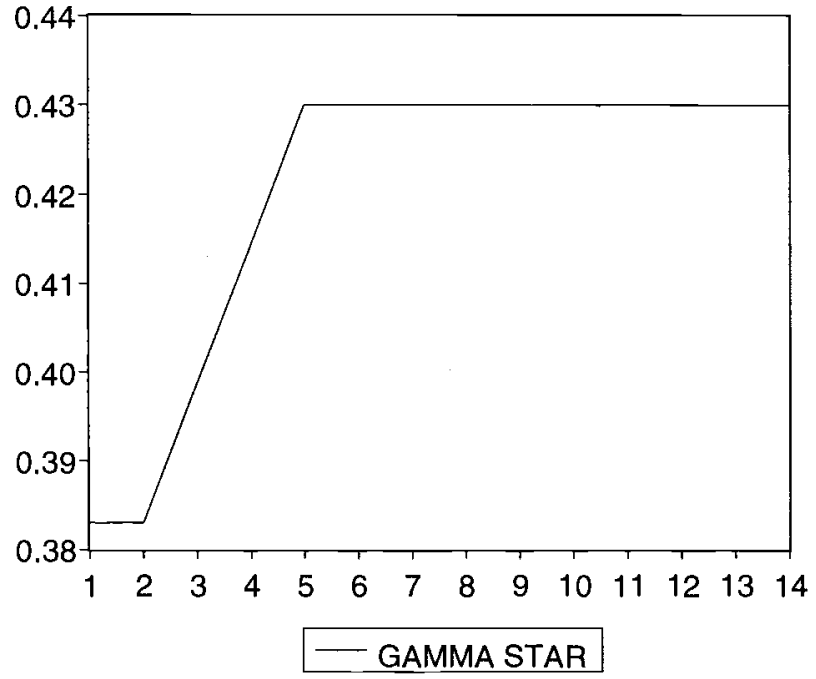

B

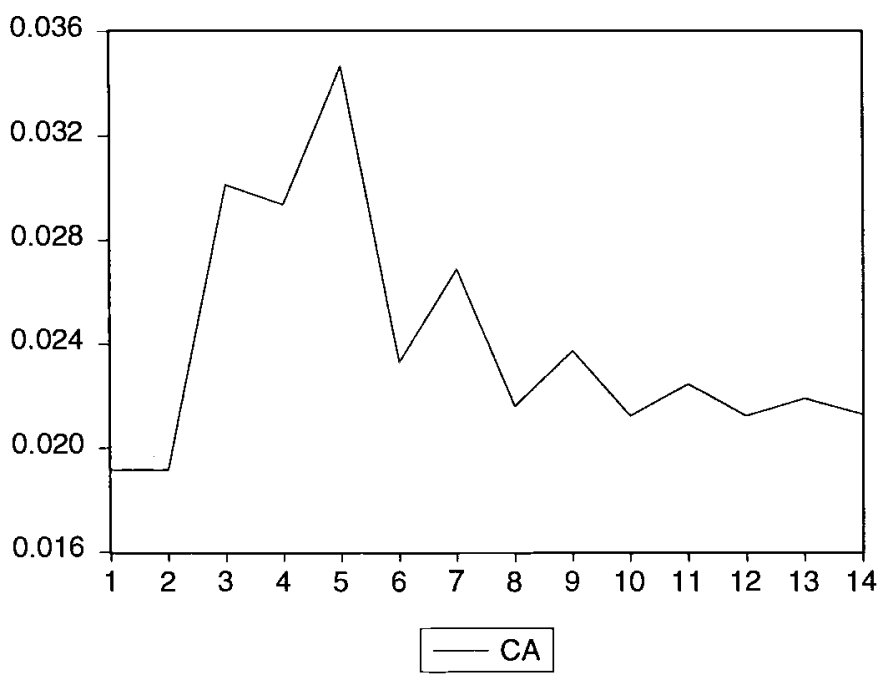

Fig. 1.1 On the equilibrium path of the current account deficit: A simulation exercise; $A$, Assumed evolution of foreigners' net demand for Mexico's liabilities; $B$, Simulated equilibrium path of Mexico's current account deficit 
likely to be easier under a flexible exchange rate regime than under a rigid one. Second, if foreigners' (net) demand for the country's liabilities declines - as is likely to be the case if there is some degree of contagion, for example - the required current account compression will also overshoot. In the immediate future the country will have to go through a very severe adjustment. This can be illustrated by the following simple example. Assume that as a result of external events - a crisis in Brazil, say - the demand for Argentine liabilities declines from the level estimated by Goldman Sachs, 48.4 percent of GDP, to 40 percent of GDP. While the long-run equilibrium current account, as calculated by Goldman Sachs, would experience a very modest decline from 2.9 percent to 2.4 percent of GDP, in the short run the adjustment would be drastic. In fact, the simple model developed above suggests that after two years the deficit would have to be compressed to approximately 0.5 percent of GDP. ${ }^{13}$

\subsection{Current Account Behavior Since the 1970s}

In this section I provide a broad analysis of current account behavior in both emerging and advanced countries. The section deals with three specific issues: (1) the distribution of the current account across regions, (2) the persistence of high current account deficits, and (3), a detailed analysis of current account reversals and their costs. The discussion of the relationship, if any, between current account deficits and financial crises is the subject of section 1.5.

\subsubsection{The Distribution of Current Account Deficits in the World Economy}

In this subsection I use data for 149 countries during 1970-97 to analyze some basic aspects of current account behavior. I am particularly interested in understanding the magnitudes of deficits through time. This first look at the data should help answer questions such as "From a historical point of view, is 4 percent of GDP a large current account deficit?" and "Historically, for how long have countries been able to run 'large' current account deficits?" The data are from the World Bank comparative data set. However, when data taken from the IMF's International Financial Statistics are used, the results obtained are very similar. Throughout the analysis I have concentrated on the current account deficit as a percentage of GDP; that is, in what follows, a positive number means that the country in question, for that particular year, has run a current account deficit. In order to organize the discussion I have divided the data into six regions: (1) industrialized countries, (2) Latin America and the Caribbean, (3) Asia, (4) Africa, (5) the Middle

13. This assumes that growth is not affected. If, as is likely, it declines, the required compression would be even larger. 
Table 1.3

Number of Observations per Region Used in Current Account Analysis

\begin{tabular}{|c|c|c|c|c|c|c|c|}
\hline Year & Industrialized & $\begin{array}{c}\text { Latin } \\
\text { America }\end{array}$ & Asia & Africa & $\begin{array}{l}\text { Middle } \\
\text { East }\end{array}$ & $\begin{array}{l}\text { Eastern } \\
\text { Europe }\end{array}$ & Total \\
\hline 1970 & 8 & 5 & 5 & 2 & 2 & 0 & 22 \\
\hline 1971 & 9 & 6 & 5 & 2 & 3 & 0 & 25 \\
\hline 1972 & 10 & 6 & 6 & 2 & 3 & 0 & 27 \\
\hline 1973 & 10 & 6 & 6 & 2 & 3 & 0 & 27 \\
\hline 1974 & 11 & 7 & 7 & 10 & 4 & 1 & 40 \\
\hline 1975 & 18 & 10 & 9 & 18 & 5 & 1 & 61 \\
\hline 1976 & 20 & 17 & 10 & 23 & 8 & 1 & 79 \\
\hline 1977 & 22 & 25 & 11 & 32 & 9 & 1 & 100 \\
\hline 1978 & 22 & 27 & 11 & 36 & 9 & 1 & 106 \\
\hline 1979 & 21 & 29 & 12 & 37 & 9 & 1 & 109 \\
\hline 1980 & 21 & 32 & 13 & 40 & 10 & 3 & 119 \\
\hline 1981 & 22 & 32 & 15 & 41 & 10 & 3 & 123 \\
\hline 1982 & 22 & 32 & 15 & 42 & 10 & 4 & 125 \\
\hline 1983 & 22 & 32 & 15 & 42 & 10 & 4 & 125 \\
\hline 1984 & 22 & 33 & 17 & 42 & 10 & 5 & 129 \\
\hline 1985 & 22 & 33 & 17 & 44 & 10 & 5 & 131 \\
\hline 1986 & 22 & 31 & 17 & 45 & 10 & 5 & 130 \\
\hline 1987 & 22 & 32 & 17 & 47 & 10 & 6 & 134 \\
\hline 1988 & 22 & 32 & 17 & 47 & 10 & 6 & 134 \\
\hline 1989 & 22 & 32 & 17 & 47 & 10 & 6 & 134 \\
\hline 1990 & 22 & 32 & 17 & 46 & 11 & 6 & 134 \\
\hline 1991 & 23 & 32 & 17 & 45 & 10 & 7 & 134 \\
\hline 1992 & 23 & 33 & 18 & 44 & 10 & 13 & 141 \\
\hline 1993 & 23 & 33 & 18 & 44 & 10 & 18 & 146 \\
\hline 1994 & 23 & 33 & 18 & 44 & 11 & 20 & 149 \\
\hline 1995 & 23 & 31 & 18 & 36 & 11 & 20 & 139 \\
\hline 1996 & 23 & 26 & 18 & 28 & 7 & 21 & 123 \\
\hline 1997 & 20 & 17 & 18 & 22 & 7 & 19 & 103 \\
\hline Total & 550 & 696 & 384 & 910 & 232 & 177 & 2,949 \\
\hline
\end{tabular}

Source: Author's calculations.

East and Northern Africa, and (6) Eastern Europe. In table 1.3 I present the number of countries in each region and year for which data are available. This table summarizes the largest data set that can be used in empirical work. As will be specified later, in some of the empirical exercises I have restricted the data set to countries with populations above half a million people and income per capita above US\$500 in 1985 purchasing power parity (PPP) terms. For a list of the countries included in the analysis, see the appendix.

Tables 1.4, 1.5, and 1.6 contain basic data on current account deficits by region for the period 1970-97. In table 1.4 I present averages by region and year. Table 1.5 contains medians, and in table 1.6 I present the 3 rd quartile by year and region. I have used the data on the 3rd quartile presented in this table as cutoff points to define "high deficit" countries. Later in this section I analyze the persistence of high deficits in each of the six regions. 
Average Current Account to GDP Deficit Ratios, by Region, 1970-97

\begin{tabular}{|c|c|c|c|c|c|c|c|}
\hline Year & Industrialized & $\begin{array}{c}\text { Latin } \\
\text { America }\end{array}$ & Asia & Africa & $\begin{array}{l}\text { Middle } \\
\text { East }\end{array}$ & $\begin{array}{l}\text { Eastern } \\
\text { Europe }\end{array}$ & Total \\
\hline 1970 & -0.02 & 7.59 & -0.52 & 0.92 & 7.86 & n.a. & 2.40 \\
\hline 1971 & -0.28 & 5.59 & 0.08 & 5.25 & -0.13 & n.a. & 1.66 \\
\hline 1972 & -1.54 & 3.86 & 1.80 & 6.16 & -4.39 & n.a. & 0.66 \\
\hline 1973 & -1.18 & 3.40 & 0.53 & 7.18 & 0.61 & n.a. & 1.04 \\
\hline 1974 & 3.00 & 3.30 & 3.55 & -3.22 & -10.14 & 1.50 & 0.24 \\
\hline 1975 & 1.49 & 2.44 & 2.02 & 4.72 & -9.52 & 3.52 & 1.81 \\
\hline 1976 & 2.20 & 1.42 & 0.81 & 5.70 & -10.59 & 3.81 & 1.60 \\
\hline 1977 & 1.86 & 4.09 & 0.90 & 3.77 & -5.88 & 5.15 & 2.26 \\
\hline 1978 & 0.52 & 3.39 & 2.82 & 8.62 & 0.77 & 1.88 & 4.28 \\
\hline 1979 & 1.43 & 4.28 & 3.54 & 6.51 & -8.18 & 1.54 & 3.35 \\
\hline 1980 & 2.22 & 7.13 & 9.40 & 7.12 & -9.02 & 2.06 & 5.02 \\
\hline 1981 & 2.47 & 10.15 & 10.15 & 10.68 & -8.00 & 3.17 & 7.30 \\
\hline 1982 & 2.41 & 9.09 & 9.94 & 12.38 & -1.67 & 1.46 & 8.02 \\
\hline 1983 & 1.24 & 6.39 & 9.52 & 8.76 & 1.61 & 1.47 & 6.11 \\
\hline 1984 & 0.99 & 4.16 & 5.83 & 6.19 & 1.32 & 0.40 & 4.14 \\
\hline 1985 & 1.17 & 2.72 & 4.67 & 6.44 & 1.45 & 1.54 & 3.82 \\
\hline 1986 & 0.98 & 5.44 & 3.60 & 6.60 & 1.30 & 2.80 & 4.43 \\
\hline 1987 & 1.04 & 5.37 & 2.24 & 4.75 & 1.25 & 0.17 & 3.51 \\
\hline 1988 & 0.91 & 4.28 & 1.65 & 5.80 & 0.54 & -1.05 & 3.41 \\
\hline 1989 & 1.20 & 5.28 & 2.85 & 4.64 & -2.99 & 0.33 & 3.24 \\
\hline 1990 & 1.18 & 4.59 & 2.31 & 4.51 & -4.73 & 2.96 & 2.88 \\
\hline 1991 & 0.68 & 7.19 & 2.56 & 4.79 & n.a. & 1.78 & 6.26 \\
\hline 1992 & 0.44 & 5.47 & 2.33 & 6.31 & 7.90 & -0.14 & 4.17 \\
\hline 1993 & -0.45 & 5.89 & 5.10 & 6.75 & 5.64 & 1.26 & 4.46 \\
\hline 1994 & -0.35 & 4.65 & 3.38 & 6.47 & -0.31 & 0.91 & 3.39 \\
\hline 1995 & -0.32 & 4.43 & 5.07 & 8.00 & -1.63 & 2.59 & 3.91 \\
\hline 1996 & -0.44 & 5.29 & 4.33 & 8.51 & -2.60 & 6.45 & 4.56 \\
\hline 1997 & -0.66 & 3.87 & 3.79 & 4.57 & -3.89 & 6.51 & 3.09 \\
\hline Total & 0.87 & 5.28 & 4.12 & 6.56 & -0.40 & 2.52 & 4.09 \\
\hline
\end{tabular}

Source: Computed by the author using raw data obtained from the World Bank.

Note: A positive number denotes a current account deficit. A negative number represents a surplus. n.a. $=$ not available.

A number of interesting features of current account behavior emerge from these tables. First, after the 1973 oil shock, there were important changes in current account balances in the industrial nations, the Middle East, and Africa. Interestingly, no discernible change can be detected in Latin America or Asia. Second, and in contrast to the previous point, the 1979 oil shock seems to have affected current account balances in every region in the world. The impact of this shock was particularly severe in Latin America, where the deficit jumped from an average of 3.4 percent of GDP in 1978 to over 10 percent of GDP in 1981. Third, these tables capture vividly the magnitude of the external adjustment undertaken by the emerging economies in the 1980s. What is particularly interesting is that, contrary 
Table 1.5

Median Current Account to GDP Deficit Ratios, by Region, 1970-97

\begin{tabular}{|c|c|c|c|c|c|c|c|}
\hline Year & Industrialized & $\begin{array}{c}\text { Latin } \\
\text { America }\end{array}$ & Asia & Africa & $\begin{array}{c}\text { Middle } \\
\text { East }\end{array}$ & $\begin{array}{l}\text { Eastern } \\
\text { Europe }\end{array}$ & Total \\
\hline 1970 & -0.41 & 4.06 & 0.94 & 0.92 & 7.86 & n.a. & 0.86 \\
\hline 1971 & -0.51 & 4.83 & 1.10 & 5.25 & 5.74 & n.a. & 1.08 \\
\hline 1972 & -1.06 & 1.70 & 1.57 & 6.16 & 2.88 & n.a. & 0.44 \\
\hline 1973 & 0.18 & 1.24 & 0.77 & 7.18 & 5.42 & n.a. & 0.95 \\
\hline 1974 & 2.94 & 4.10 & 3.02 & 2.39 & 0.14 & 1.50 & 2.97 \\
\hline 1975 & 1.34 & 4.52 & 3.23 & 6.56 & -2.73 & 3.52 & 3.40 \\
\hline 1976 & 2.71 & 1.41 & 0.62 & 5.00 & -6.65 & 3.81 & 3.27 \\
\hline 1977 & 2.11 & 3.80 & -0.03 & 4.24 & -3.71 & 5.15 & 2.84 \\
\hline 1978 & 0.68 & 3.48 & 2.74 & 9.95 & 3.01 & 1.88 & 3.60 \\
\hline 1979 & 0.66 & 4.68 & 3.73 & 6.52 & -8.89 & 1.54 & 3.32 \\
\hline 1980 & 2.35 & 5.59 & 5.03 & 8.36 & -3.96 & 4.95 & 4.66 \\
\hline 1981 & 2.73 & 9.06 & 5.92 & 10.09 & 1.46 & 2.72 & 6.58 \\
\hline 1982 & 2.02 & 7.60 & 5.10 & 9.85 & -1.53 & 1.88 & 6.41 \\
\hline 1983 & 0.88 & 4.70 & 7.18 & 6.59 & 5.10 & 1.48 & 4.33 \\
\hline 1984 & 0.22 & 3.66 & 2.12 & 3.76 & 4.89 & 1.43 & 2.51 \\
\hline 1985 & 0.98 & 2.07 & 3.13 & 4.42 & 2.61 & 1.51 & 2.91 \\
\hline 1986 & -0.12 & 2.99 & 2.42 & 3.76 & 2.30 & 1.93 & 2.68 \\
\hline 1987 & 0.42 & 4.15 & 1.34 & 5.22 & 3.04 & 0.76 & 2.61 \\
\hline 1988 & 1.15 & 2.25 & 2.68 & 5.50 & 2.00 & 0.72 & 2.66 \\
\hline 1989 & 1.54 & 4.41 & 3.35 & 3.76 & -0.39 & 1.70 & 2.85 \\
\hline 1990 & 1.60 & 3.00 & 3.41 & 3.78 & -0.58 & 3.69 & 2.83 \\
\hline 1991 & 0.91 & 4.83 & 3.17 & 3.64 & 9.74 & 0.70 & 3.02 \\
\hline 1992 & 0.86 & 4.34 & 1.94 & 5.65 & 7.29 & 0.40 & 3.01 \\
\hline 1993 & 0.55 & 4.60 & 4.18 & 6.81 & 4.20 & 1.58 & 3.18 \\
\hline 1994 & -0.37 & 3.19 & 4.63 & 5.65 & -0.38 & 1.39 & 2.49 \\
\hline 1995 & -0.71 & 3.90 & 4.91 & 4.81 & -2.14 & 1.99 & 2.70 \\
\hline 1996 & -0.56 & 3.97 & 4.76 & 4.15 & -0.99 & 4.50 & 3.28 \\
\hline 1997 & -0.57 & 4.12 & 3.61 & 3.71 & -2.39 & 6.29 & 2.94 \\
\hline Total & 0.77 & 4.12 & 3.14 & 5.33 & 1.95 & 1.93 & 3.17 \\
\hline
\end{tabular}

Source: Computed by the author using raw data obtained from the World Bank.

Note: n.a. $=$ not available

to popular folklore, this adjustment was not confined to the Latin American region. Indeed, the nations of Asia and Africa also experienced severe reductions in their deficits during this period. Fourth, the industrialized countries regained sustained surpluses only after 1993. Finally, during the most recent period, current account deficits have been rather modest from a historical perspective. This has been the case in every region, with the important exception of Eastern Europe.

The data on 3rd quartiles presented in table 1.6 show that 25 percent of the countries in our sample had, at one point or another, a current account deficit in excess of 7.22 percent of GDP. Naturally, as the table shows, the 3 rd quartile differs for each region and year, with the largest values corresponding to Africa and Latin America. I use the 3rd-quartile data in table 
Third Quartile of Current Account to GDP Deficit Ratios, by Region, 1970-97

\begin{tabular}{|c|c|c|c|c|c|c|c|}
\hline Year & Industrialized & $\begin{array}{c}\text { Latin } \\
\text { America }\end{array}$ & Asia & Africa & $\begin{array}{l}\text { Middle } \\
\text { East }\end{array}$ & $\begin{array}{l}\text { Eastern } \\
\text { Europe }\end{array}$ & Total \\
\hline 1970 & 0.64 & 6.86 & 1.28 & 1.93 & 9.85 & n.a. & 4.06 \\
\hline 1971 & 0.43 & 7.77 & 1.74 & 8.28 & 9.31 & n.a. & 4.55 \\
\hline 1972 & 0.30 & 2.37 & 3.63 & 11.96 & 5.30 & n.a. & 2.59 \\
\hline 1973 & 1.33 & 4.12 & 1.30 & 9.99 & 5.81 & n.a. & 4.12 \\
\hline 1974 & 4.41 & 10.05 & 5.61 & 4.64 & 14.44 & 1.50 & 5.52 \\
\hline 1975 & 4.46 & 6.78 & 5.06 & 8.44 & 13.98 & 3.52 & 7.75 \\
\hline 1976 & 4.38 & 4.23 & 6.19 & 8.80 & 4.36 & 3.81 & 5.47 \\
\hline 1977 & 3.62 & 7.37 & 4.49 & 7.86 & 2.47 & 5.15 & 6.35 \\
\hline 1978 & 2.50 & 7.07 & 4.80 & 12.85 & 9.17 & 1.88 & 9.17 \\
\hline 1979 & 2.76 & 6.60 & 6.57 & 12.30 & 5.17 & 1.54 & 7.62 \\
\hline 1980 & 3.70 & 12.92 & 8.46 & 13.11 & 2.63 & 5.99 & 10.60 \\
\hline 1981 & 4.32 & 15.06 & 10.04 & 12.85 & 5.85 & 7.38 & 11.76 \\
\hline 1982 & 4.05 & 11.74 & 11.49 & 14.48 & 8.26 & 2.63 & 10.57 \\
\hline 1983 & 2.41 & 8.33 & 9.01 & 12.39 & 7.73 & 2.61 & 8.33 \\
\hline 1984 & 3.08 & 6.56 & 4.88 & 8.78 & 8.17 & 1.46 & 5.69 \\
\hline 1985 & 3.75 & 6.05 & 4.82 & 9.68 & 7.45 & 1.85 & 6.42 \\
\hline 1986 & 3.51 & 7.75 & 5.16 & 8.19 & 9.36 & 4.69 & 6.44 \\
\hline 1987 & 3.24 & 8.79 & 4.07 & 9.69 & 6.35 & 2.53 & 6.35 \\
\hline 1988 & 3.03 & 7.67 & 4.30 & 9.49 & 4.65 & 1.75 & 6.51 \\
\hline 1989 & 3.60 & 7.61 & 5.91 & 7.02 & 5.43 & 2.02 & 5.69 \\
\hline 1990 & 3.37 & 7.64 & 6.08 & 8.93 & 2.77 & 8.25 & 6.13 \\
\hline 1991 & 2.78 & 11.57 & 6.61 & 9.05 & 17.96 & 3.51 & 7.57 \\
\hline 1992 & 2.67 & 8.04 & 4.70 & 9.01 & 15.72 & 3.68 & 6.86 \\
\hline 1993 & 1.65 & 8.81 & 6.42 & 8.80 & 11.45 & 4.45 & 7.86 \\
\hline 1994 & 1.83 & 7.27 & 6.46 & 8.88 & 6.62 & 3.57 & 6.50 \\
\hline 1995 & 1.64 & 5.42 & 8.06 & 10.42 & 4.24 & 5.54 & 6.61 \\
\hline 1996 & 1.83 & 7.02 & 8.10 & 9.25 & 3.32 & 9.16 & 7.60 \\
\hline 1997 & 1.91 & 5.93 & 6.89 & 7.05 & 2.94 & 11.07 & 6.29 \\
\hline 1998 & & & & & & & \\
\hline Total & 3.06 & 8.16 & 6.37 & 10.09 & 7.14 & 4.84 & 7.22 \\
\hline
\end{tabular}

Source: Computed by the author using raw data obtained from the World Bank.

Note: n.a. $=$ not available

1.6 to define "large current account deficit" countries. In particular, if during a given year a particular country's deficit exceeds its region's 3rd quartile, I classify it as being a "high-deficit country." 14 An important policy question is how persistent high deficits are. I deal with this issue in table 1.7, where I have listed those countries that have had a "high current account deficit" for at least five years in a row. The results are quite interesting and indicate that a rather small number of countries experienced very long periods of high deficits. In fact, I could detect only eleven countries with high

14. Notice, however, that the actual cutoff points correspond to fairly large deficits even for the Middle Eastern countries. 
Table 1.7 Countries with Persistently High Current Account Deficits, by Region, 1975-97

\begin{tabular}{|c|c|}
\hline Region & Period \\
\hline \multicolumn{2}{|c|}{ Industrialized Countries } \\
\hline Australia & 1981-97 \\
\hline Canada & 1989-94 \\
\hline Greece & $1979-85$ \\
\hline Ireland & $1976-85$ \\
\hline Malta & $1993-97$ \\
\hline New Zealand & $1975-88,1993-97$ \\
\hline \multicolumn{2}{|c|}{ Latin America and the Caribbean } \\
\hline Grenada & $1986-96$ \\
\hline Guyana & $1979-85$ \\
\hline Honduras & $1975-79$ \\
\hline Nicaragua & $1980-90$ \\
\hline \multicolumn{2}{|l|}{ Asia } \\
\hline Bhutan & $1981-97$ \\
\hline Laos & $1980-90$ \\
\hline Maldives & $1980-85$ \\
\hline Nepal & $1985-97$ \\
\hline Vietnam & 1993-97 \\
\hline \multicolumn{2}{|l|}{ Africa } \\
\hline Congo & $1990-97$ \\
\hline Côte D'Ivoire & $1980-92$ \\
\hline Equatorial Guinea & $1987-91$ \\
\hline Guinea-Bissau & $1982-94$ \\
\hline Mali & $1984-89$ \\
\hline Mauritania & $1975-88$ \\
\hline Mozambique & $1986-96$ \\
\hline São Tomé & $1981-90$ \\
\hline Somalia & $1982-87$ \\
\hline Sudan & $1990-97$ \\
\hline Swaziland & $1978-85$ \\
\hline Tanzania & $1990-97$ \\
\hline \multicolumn{2}{|l|}{ Middle East } \\
\hline Cyprus & $1977-81$ \\
\hline \multicolumn{2}{|l|}{ Eastern Europe } \\
\hline None & \\
\hline
\end{tabular}

Source: Computed by the author.

Note: The countries in this list have had a "high current account deficit" for at least five years in a row. See the text for the exact definition of "high current account deficit."

deficits for ten or more years. Of these, five are in Africa, three are in Asia, and, perhaps surprisingly, only two are in Latin America and the Caribbean. Interestingly enough, Australia and New Zealand are among the very small group of countries with a streak of high current account deficits in excess of ten years. In the subsection that follows I will analyze some of the most important characteristics of deficits reversals. 


\subsubsection{Current Account Reversals: How Common, How Costly?}

In this section I provide an analysis of current account reversals. In particular I ask three questions: First, how common are large current account deficit reversals? Second, from a historical point of view, have these reversals been associated with currency or financial crashes? Third, how costly, in terms of economic performance indicators, have these reversals been? With respect to this third point, I argue that the most severe effect of current account reversals on economic performance takes place indirectly, through their impact on investment. The analysis presented in this subsection complements the results in a recent important paper by Milesi-Ferretti and Razin (2000). ${ }^{15}$

I use two alternative definitions of current account reversals: Reversall is defined as a reduction in the deficit of at least three percent of GDP in one year, and Reversal2 is defined as a reduction of the deficit of at least 3 percent of GDP in a three-year period. Due to space considerations, the results reported here correspond to those obtained when the Reversall definition was used. However, the results obtained under the alternative-and less strict-definition, Reversal2, were very similar to those discussed in this subsection. ${ }^{16}$

The first question I ask is how common reversals are. This issue is addressed in table 1.8, where I present tabulations by region, as well as for the complete sample, for the Reversall variable. As may be seen, for the sample as a whole the incidence of "reversals" was equal to 16.7 percent of the yearly episodes. This reversal occurrence varied across regions; not surprisingly, given the definition of reversals, the lowest incidence is in the industrialized countries ( 6 percent). The two highest regions are Africa and the Middle East, with 27 and 26 percent of reversals respectively. Both from a theoretical and from a policy perspective, it is important to determine whether these reversals are short lived or sustained. Short-term reversals may be the result of consumption smoothing, while more permanent ones are likely to be the consequence of policy-related external adjustments. I address this issue by asking in how many "reversal" cases the current account deficit was still lower three years after the reversal was detected. The answer lies in the two-way tabulation tables presented in table 1.9. ${ }^{17}$ These results indicate that, for the sample as a whole, 45 percent of the "reversals" were translated into a medium-term (three-year) improvement in the current account balance. The degree of permanency of these reversals varied by re-

15. My data set, however, is larger than that of Milesi-Ferretti and Razin (2000).

16. These definitions of reversal are somewhat different from those used by Milesi-Ferretti and Razin (2000).

17. This table includes only countries whose population is greater than half a million people and whose GDP per capita is above \$500. It also excludes countries whose current account was in surplus. 


\begin{tabular}{|c|c|c|c|}
\hline & Frequency & Percent & Cumulative \\
\hline \multicolumn{4}{|c|}{ Industrialized } \\
\hline 0 & 451 & 93.96 & 93.96 \\
\hline 1 & 29 & 6.04 & 100.00 \\
\hline Total & 480 & 100.00 & \\
\hline \multicolumn{4}{|c|}{ Latin America } \\
\hline 0 & 359 & 81.04 & 81.04 \\
\hline 1 & 84 & 18.96 & 100.00 \\
\hline Total & 443 & 100.00 & \\
\hline \multicolumn{4}{|l|}{ Asia } \\
\hline 0 & 250 & 85.91 & 85.91 \\
\hline 1 & 41 & 14.09 & 100.00 \\
\hline Total & 291 & 100.00 & \\
\hline \multicolumn{4}{|l|}{ Africa } \\
\hline 0 & 230 & 72.56 & 72.56 \\
\hline 1 & 87 & 27.44 & 100.00 \\
\hline Total & 317 & 100.00 & \\
\hline \multicolumn{4}{|c|}{ Middle East } \\
\hline 0 & 156 & 74.29 & 74.29 \\
\hline 1 & 54 & 25.71 & 100.00 \\
\hline Total & 210 & 100.00 & \\
\hline \multicolumn{4}{|c|}{ Eastern Europe } \\
\hline 0 & 134 & 85.90 & 85.90 \\
\hline 1 & 22 & 14.10 & 100.00 \\
\hline Total & 156 & 100.00 & \\
\hline \multicolumn{4}{|c|}{ All countries } \\
\hline 0 & 1580 & 83.29 & 83.29 \\
\hline 1 & 317 & 16.71 & 100.00 \\
\hline Total & 1897 & 100.00 & \\
\hline
\end{tabular}

Source: Author's calculations.

Note: Reversals are defined as a reduction in the deficit of at least 3 percent of GDP in one year. A number 1 captures reversals. The data set has been restricted to countries with populations in excess of half a million people and GDP per capita over \$500 at PPP value.

gion, however. In the advanced countries, 75 percent of the reversals were sustained after three years; the smallest percentage corresponds to the Latin American nations, where only 37 percent of the reversals were sustained after three years.

In their influential paper, Milesi-Ferretti and Razin (2000) analyzed the effects of current account reversals on economic performance and in particular on GDP growth. They relied on two methods to address this issue. They first used a "before and after" approach and tentatively concluded that "reversals in current account deficits are not necessarily associated with domestic output compression" (302). Since "before and after" analyses are subject to a number of serious shortcomings, Milesi-Ferretti and Razin also address the issue by estimating a number of multiple regressions 


\begin{tabular}{lrrr}
\hline & \multicolumn{3}{c}{$\begin{array}{c}\text { Reversal in } 1 \text { year } \\
\text { (Greater than } 3 \%)\end{array}$} \\
\cline { 2 - 4 } CAD Improvement & 0 & 1 & Total \\
\hline Industrial & & & \\
0 & 128 & 5 & 133 \\
1 & 156 & 12 & 168 \\
Total & 284 & 17 & 301 \\
Latin America & & & \\
0 & 156 & 33 & 189 \\
1 & 174 & 19 & 193 \\
Total & 330 & 52 & 382 \\
Asia & & & \\
0 & 137 & 18 & 155 \\
1 & 116 & 13 & 129 \\
Total & 253 & 31 & 284 \\
Africa & & & \\
0 & 211 & 72 & 283 \\
1 & 231 & 61 & 292 \\
Total & 442 & 133 & 575 \\
Middle East & & & \\
0 & 45 & 11 & 56 \\
1 & 62 & 8 & 70 \\
Total & 107 & 19 & 126 \\
Eastern Europe & & & \\
0 & 67 & 6 & 73 \\
1 & 36 & 6 & 42 \\
Total & 103 & 12 & 115 \\
\hline
\end{tabular}

Source: Author's calculations.

Note: CAD improvement is in a three-year period, forward.

on different samples. Their dependent variable is the rate of per capita output growth, and the independent variables include a measure of exchange rate overvaluation, an index of openness, the level of indebtedness, initial GDP, and the investment-to-GDP ratio, among others. After analyzing the results obtained from this regression analysis, the authors argue that "reversals ... are not systematically associated with a growth slowdown" (303).

Milesi-Ferretti and Razin (2000) reach this conclusion after estimating growth equations that control for investment (among other variables). It is highly probable, however, that current account reversals affect investment itself, and that through this channel they affect real GDP growth. The reason for this potential effect of reversals is rather simple: investment is financed by the sum of national and foreign saving. The latter, of course, is exactly equal to the current account deficit. Thus, any current account reversal will imply a reduction in foreign saving. What will happen to aggregate saving, 
and thus to investment, will depend on the relationship between foreign and national saving. The existing empirical evidence on this matter strongly suggests that foreign saving partially, and only partially, crowds out domestic saving. Edwards (1996), for example, estimated a number of private saving equations for developing countries and found that the coefficient of the current account deficit was significant and in the neighborhood of -0.4 . Loayza, Schmidt-Hebbel, and Servén (2000) used a new data set on private savings in emerging economies and estimated that the coefficient of the current account deficit was -0.33 and highly significant. These results, then, suggest that a decline in foreign saving - that is, a lower current account deficit - will reduce aggregate saving and, thus, aggregate investment. Since there is ample evidence supporting the idea that investment has a positive effect on growth, the previous argument would suggest that, in contrast with Milesi-Ferretti and Razin's (2000) claim, current account reversals will have a negative, albeit indirect, effect on growth.

In order to investigate whether indeed current account reversals have affected aggregate investment negatively, I estimated a number of investment equations using panel data for a large number of countries for the period 1970-97. The recent empirical literature on investment, including Attanasio, Picci, and Scorcu (2000), indicates that investment exhibits a strong degree of persistence through time. This suggests estimating equations of the following type: ${ }^{18}$

$$
\begin{aligned}
\operatorname{INVGDP}_{t j}= & \beta \text { INVGDP }_{t-1, j}+\delta \operatorname{GOVCONS}_{t j} \\
& +\phi \text { TRADE_OPENNESS }_{t j}+\gamma \operatorname{REVERSAL}_{t j}+\omega_{t j},
\end{aligned}
$$

where INVGDP is the investment-to-GDP ratio, GOVCONS is the ratio of government expenditure to GDP, and TRADE_OPENNESS is an index that captures the degree of openness of the economy. REVERSAL is a variable that takes the value of 1 if the country in question has been subject to a current account reversal, and 0 otherwise. ${ }^{19}$ Finally, $\omega$ is an error term, which takes the following form:

$$
\omega_{t j}=\varepsilon_{j}+\mu_{t j},
$$

where $\varepsilon_{j}$ is a country-specific error term and $\mu_{t j}$ is an independently and identically distributed (i.i.d.) disturbance with the standard characteristics.

The estimation of equation (10) presents two problems. First, it is well known from early work on dynamic panel estimation by Nerlove (1971) that if the error contains a country-specific term, the coefficient of the lagged de-

18. On recent attempts to estimate investment equations using a cross section of countries see, for example, Barro and Sala-i-Martin (1995) and Attanasio, Picci, and Scorcu (2000).

19. In principle, the log of initial GDP may also be included. However, because of the panel nature of the data, and given the estimation procedures used, this is not possible. 
pendent variable will be biased upward. There are several ways of handling this potential problem. Possibly the most basic approach is using a fixed effect model, in which a country dummy (one hopes) picks up the effect of the country-specific disturbance. A second way is to estimate the instrumental variables procedure recently proposed by Arellano and Bond (1991) for dynamic panel data. This method consists of differentiating the equation in question, equation (10) in our case, in order to eliminate the country-specific disturbance $\varepsilon_{j}$. The differenced equation is then estimated using instrumental variables, where the lagged dependent variable (in levels), the predetermined variables (also in levels), and the first differences of the exogenous variables are used as instruments. In this paper I report results from the estimation of equation (10) using both a fixed effect procedure and the Arellano and Bond method.

A second problem in estimating equation (10) is that, since current account reversals are not drawn from a random experiment, the REVERSAL ${ }_{j t}$ dummy is possibly correlated with the error term. Under these circumstances, the estimated coefficients in equation (10) will be biased and misleading. In order to deal with this problem I follow the procedure recently suggested by Heckman, Ichimura, and Todd $(1997,1998)$ for estimating "treatment interventions" models. This procedure consists of estimating the equation in question using observations that have a common support for both the treated and the nontreated. In the case at hand, countries that experience a reversal are considered to be subject to the "treatment intervention." From a practical point of view, a two-step procedure is used. First, the conditional probability of countries facing a reversal, called the propensity score, is first estimated using a probit regression. Second, the equation of interest is estimated using only observations whose estimated probability of reversal falls within the interval of estimated probabilities for countries with actual reversals. I follow the Heckman, Ichimura, and Todd $(1997,1998)$ sample correction both for the fixed effect and the Arellano and Bond procedures. In estimating the propensity scores I used a panel data probit procedure and included as regressors the level of the current account deficit in the previous period, the level of the fiscal deficit, domestic credit creation, and time-specific dummies. The results obtained from this first step are not presented here due to space consideration but are available on request. Table 1.10 contains the results of estimating investment equation (10) on an unbalanced panel of 128 countries for the period 1971-97. In part A of table 1.10 I present the results obtained from the estimation of the Arellano-Bond instrumental variables procedure. In part B of table 1.10 I present the results from the fixed effect estimation. In both cases I have introduced the REVERSALS indicator both contemporaneously and with a one-period lag. In the Arellano-Bond estimates, the standard errors have been computed using White's robust procedure that corrects for 


\begin{tabular}{|c|c|c|c|c|c|c|}
\hline INVGDP & Coeff. & $\begin{array}{l}\text { Robust } \\
\text { Std. Err. }\end{array}$ & $z$ & $P>|z|$ & \multicolumn{2}{|c|}{$95 \%$ Conf. Interval } \\
\hline \multicolumn{7}{|c|}{ A. Arellano-Bond Instrumental Variables ${ }^{\mathrm{a}}$} \\
\hline INVGDP LD & 0.6212481 & 0.0835012 & 7.44 & 0.000 & 0.4575887 & 0.7849075 \\
\hline GOVCON D1 & 0.0819257 & 0.0106311 & 0.77 & 0.441 & -0.1264401 & 0.2902916 \\
\hline REV D1 & -2.021207 & 0.2545002 & -7.94 & 0.000 & -2.520018 & -1.522396 \\
\hline REVLAG & -0.8834781 & 0.2235849 & -3.95 & 0.000 & -1.321696 & -0.4452596 \\
\hline TRADE D1 & 0.0436178 & 0.0127593 & 3.42 & 0.001 & 0.0186101 & 0.0686255 \\
\hline _CONS D1 & -0.0480371 & 0.0169209 & -2.84 & 0.005 & -0.0812014 & -0.0148727 \\
\hline Number of obs. & 1,800 & & & & & \\
\hline Number of groups & 127 & & & & & \\
\hline Wald $\chi^{2}$ & 181.56 & & & & & \\
\hline $\begin{array}{l}\text { Minimum number } \\
\text { of obs. }\end{array}$ & 1 & & & & & \\
\hline Maximum number & & & & & & \\
\hline of obs. & 25 & & & & & \\
\hline \multirow{3}{*}{$\begin{array}{l}\text { Mean number } \\
\text { of obs. }\end{array}$} & & & & & & \\
\hline & 14.17323 & & & & & \\
\hline & Coeff. & Std. Err. & $t$ & $P>|t|$ & \multicolumn{2}{|c|}{$95 \%$ Conf. Interval } \\
\hline \multicolumn{7}{|c|}{ B. Fixed Effects Method ${ }^{\mathrm{b}}$} \\
\hline INVGDP1 & 0.7655012 & 0.0139967 & 54.69 & 0.000 & 0.7380497 & 0.7929527 \\
\hline GOVCON & 0.0326171 & 0.0186247 & 1.75 & 0.080 & -0.0039113 & 0.0691455 \\
\hline REV & -2.05903 & 0.1622943 & -12.69 & 0.000 & -2.377336 & -1.740724 \\
\hline REVLAG & -0.8404217 & 0.1585791 & -5.30 & 0.000 & -1.151441 & -0.5294026 \\
\hline TRADE & 0.0324689 & 0.0051885 & 6.26 & 0.000 & 0.0222927 & 0.042645 \\
\hline _CONS & 3.266194 & 0.4745214 & 6.88 & 0.000 & 2.335521 & 4.196867 \\
\hline sigma_u & 1.6838827 & & & & & \\
\hline sigma_e & 2.4746612 & & & & & \\
\hline$\rho^{\mathrm{c}}$ & 0.31647855 & & & & & \\
\hline \multicolumn{7}{|l|}{$R^{2}$} \\
\hline within & 0.6523 & & & & & \\
\hline between & 0.9301 & & & & & \\
\hline overall & 0.8357 & & & & & \\
\hline Number of obs. & 1,927 & & & & & \\
\hline Number of groups & 128 & & & & & \\
\hline \multicolumn{7}{|l|}{ Obs. per group } \\
\hline minimum & 1 & & & & & \\
\hline average & 15.1 & & & & & \\
\hline maximum & 26 & & & & & \\
\hline$F(5,1794)$ & 672.98 & & & & & \\
\hline Prob $>F$ & 0.0000 & & & & & \\
\hline
\end{tabular}

${ }^{a}$ Arellano-Bond dynamic panel data. Group variable $(i)$ : imfcode; time variable $(t)$ : year. Arellano-Bond test that average autocovariance in residuals of order 1 is 0 : $\mathrm{H} 0$, no autocorrelation; $z=-4.46$; Prob $>z$ $=0.0000$. Arellano-Bond test that average autocovariance in residuals of order 2 is $0: \mathrm{H} 0$, no autocorrelation; $z=-1.08$; Prob $>z=0.2809$.

${ }^{b}$ Fixed-effects (within) regression. Group variable $(i)$ : imfcode. $F$ test that all $\mathrm{u} \_\mathrm{i}=0: F(127,1794)=2.61$; Prob $>F=0.0000$.

'Fraction of variance due to $\mathrm{u} \_$i. 
heteroskedasticity. The results obtained are quite interesting. In both panels the coefficient of the lagged dependent variable is relatively high, capturing the presence of persistence. Notice, however, that the coefficient is significantly smaller when the Arellano-Bond procedure is used. The coefficient of GOVCON is positive and nonsignificant. The estimated coefficient of trade openness is significant and positive, indicating that, after controlling for other factors, countries with a more open trade sector will tend to a higher investment-to-GDP ratio. More importantly for this paper, the coefficients of the contemporaneous and lagged reversal indicator are significantly negative, with very similar point estimates. Interestingly, when the REVERSAL variable was added with a two-year lag, its estimated coefficient was not significant at conventional levels.

In order to check for the robustness of these results, I also estimated equation (10) using alternative samples and definitions of current account reversals. The results obtained provide a strong support to those shown here and indicate that, indeed, current account reversals have affected economic performance negatively through the investment channel. An important question is whether the compression in investment is a result of private or public sector behavior. An analysis undertaken on a smaller sample (forty-four countries) suggests that, although both private- and public-sector investment are negatively affected by current account reversals, the impact is significantly higher on private investment. According to these estimates, available from the author, a current account reversal results in a decline in private investment equal to 1.8 percent of GDP; the long-term reduction of public-sector investment is estimated to be, on average, 0.5 percent of GDP.

An important question is whether current account reversals have affected economic growth through other channels. I investigated this issue by using the large data set to estimate a number of basic growth equations of the following type.

$$
\begin{aligned}
\text { GROWTH }_{t j}= & \beta \text { INVGDP }_{t j}+\delta \text { GOVCONS }_{t j} \\
& +\phi \text { TRADE_OPENNESS }_{t j}+\theta \text { LOGGDPO }_{j} \\
& +\gamma \text { REVERSAL }_{t j}+\xi_{t j},
\end{aligned}
$$

where GROWTH ${ }_{t j}$ is growth of GDP per capita in country $j$ during year $t$, and $\mathrm{LOGGDPO}_{j}$ is the initial level of GDP (1970) for country $j$. As Barro and Sala-i-Martin (1995) have pointed out, the coefficient of GOVCONS is expected to be negative, while that of openness is expected to be positive. If there is a catching-up in growth, we would expect that the estimated coefficient of the logarithm of 1970 GDP per capita will be negative. The main interest of this analysis is the coefficient of REVERSAL. If sharp and large reductions in the current account deficit have a negative effect on investment, we would expect the estimated $\gamma$ to be significantly negative. The er- 
$\operatorname{ror} \xi_{t j}$ is assumed to be heteroskedastic, with a different variance for each country (panel). Thus, assuming $k$ panels (countries):

$$
E\left(\xi \xi^{\prime}\right)=\left(\begin{array}{cccc}
\sigma_{1}^{2} \boldsymbol{I} & 0 & \ldots & 0 \\
0 & \sigma_{2}^{2} \boldsymbol{I} & \ldots & 0 \\
\cdot & \cdot & \cdot & \cdot \\
\cdot & \cdot & \cdot & \cdot \\
\cdot & \cdot & . & \cdot \\
0 & 0 & \ldots & \sigma_{k}^{2} \boldsymbol{I}
\end{array}\right)
$$

Equation (12) was estimated using the feasible generalized least squares procedure (FGLS) suggested by Beck and Katz (1995) for unbalanced panels. The samples in the different estimations were determined by the availability of data on the different regressors. The data were obtained from the World Bank and from the Summer and Hestons data set. In the base estimates I used the definition of current account reversals given by Reversall above. The basic results obtained from the estimation of equation (11) are presented in table 1.11. In addition to the regressors in equation (11), I introduced time-specific dummy variables. As may be seen from the table, the results obtained support the hypothesis that current account reversals have had a negative effect on GDP per capita growth, even after controlling by investment. Moreover, the coefficients for the other variables in the regression have the expected signs and are significant at conventional levels. When alternative estimation techniques were used, including fixed effects, the results obtained were very similar. ${ }^{20}$

\subsection{Current Account Deficits and Financial Crises: How Strong Is the Link?}

As we pointed out in section 1.2 of this paper, a large number of recent empirical studies have been unable to find a strong and significant connection between large current account deficits and financial crises (Frankel and Rose 1996). However, much of the policy literature - both from investment banks and from the multilateral institutions - insists that large deficits have been at the center of recent crises. In this section, I address this issue by analyzing in some detail the evidence on financial crises in a large cross section of countries. The section is organized as follows: In section 1.5.1, I deal with the definition of crisis. In section 1.5.2, I provide some preliminary evidence on the connection between current account reversals and crises, as well as between high current account deficits and crises. In this analysis I use

20. Naturally, when fixed effects are used it is not possible to include (the log of) initial GDP as a regressor. 

Heteroskedastic Panels

\begin{tabular}{|c|c|c|c|c|c|c|}
\hline \multirow{2}{*}{$\frac{\text { GDP Growth }}{\text { INVGDP }}$} & \multirow{2}{*}{$\frac{\text { Coeff. }}{0.1732786}$} & \multirow{2}{*}{$\begin{array}{c}\text { Std. Err. } \\
0.0129535\end{array}$} & \multirow{2}{*}{$\frac{z}{13.38}$} & \multirow{2}{*}{$\frac{P>|z|}{0.000}$} & \multicolumn{2}{|c|}{$95 \%$ Conf. Interval } \\
\hline & & & & & 0.1478901 & 0.198667 \\
\hline GOVCON & -0.044147 & 0.0129061 & -3.42 & 0.001 & -0.0694425 & -0.0188514 \\
\hline TRADE & 0.0066118 & 0.0021185 & 3.12 & 0.002 & 0.0024595 & 0.010764 \\
\hline LOGGPP0 & -0.7458834 & 0.0754805 & -9.88 & 0.000 & -0.8938225 & -0.5979443 \\
\hline REV & -0.8387433 & 0.2063497 & -4.06 & 0.000 & -1.243181 & -0.4343053 \\
\hline REVLAG & -0.3106008 & 0.2014468 & -1.54 & 0.123 & -0.7054293 & 0.0842277 \\
\hline D73 & 1.270318 & 0.759329 & 1.67 & 0.094 & -0.2179398 & 2.758575 \\
\hline D74 & -1.342419 & 0.7482716 & -1.79 & 0.073 & -2.809004 & 0.1241666 \\
\hline D75 & -3.115973 & 0.7482444 & -4.16 & 0.000 & -4.582505 & -1.649441 \\
\hline D76 & 0.6267746 & 0.7248618 & 0.86 & 0.387 & -0.7939283 & 2.047478 \\
\hline D77 & -0.9757318 & 0.6522791 & -1.50 & 0.135 & -2.254175 & 0.3027116 \\
\hline D78 & 0.1379759 & 0.5050662 & 0.27 & 0.785 & -0.8519357 & 1.127887 \\
\hline D79 & -1.096983 & 0.6317958 & -1.74 & 0.083 & -2.33528 & 0.1413142 \\
\hline D80 & -2.360201 & 0.6280218 & -3.76 & 0.000 & -3.591101 & -1.129301 \\
\hline D81 & -2.826354 & 0.6242467 & -4.53 & 0.000 & -4.049855 & -1.602853 \\
\hline D82 & -4.194326 & 0.6217559 & -6.75 & 0.000 & -5.412945 & -2.975707 \\
\hline D83 & -2.990355 & 0.6199746 & -4.82 & 0.000 & -4.205483 & -1.775227 \\
\hline D84 & -1.221758 & 0.6185186 & -1.98 & 0.048 & -2.434032 & -0.0094836 \\
\hline D85 & -1.784731 & 0.6187208 & -2.88 & 0.004 & -2.997401 & -0.5720605 \\
\hline D86 & -1.75282 & 0.617261 & -2.84 & 0.005 & -2.962629 & -0.5430107 \\
\hline D87 & -1.596635 & 0.6173792 & -2.59 & 0.010 & -2.806676 & -0.3865935 \\
\hline D88 & -0.7132081 & 0.6150168 & -1.16 & 0.246 & -1.918619 & 0.4922027 \\
\hline D89 & -1.492796 & 0.6147887 & -2.43 & 0.015 & -2.69776 & -0.2878324 \\
\hline D90 & -2.005303 & 0.6140373 & -3.27 & 0.001 & -3.208794 & -0.8018121 \\
\hline D91 & -2.686583 & 0.6082038 & -4.42 & 0.000 & -3.878641 & -1.494526 \\
\hline D92 & -2.38132 & 0.6155925 & -3.87 & 0.000 & -3.587859 & -1.17478 \\
\hline D93 & -2.23038 & 0.6150288 & -3.63 & 0.000 & -3.435814 & -1.024945 \\
\hline D94 & -0.8790476 & 0.6164939 & -1.43 & 0.154 & -2.087353 & 0.3292582 \\
\hline D95 & -0.9938183 & 0.5940141 & -1.67 & 0.094 & -2.158065 & 0.170428 \\
\hline D96 & -1.480438 & 0.6129868 & -2.42 & 0.016 & -2.68187 & -0.2790063 \\
\hline D97 & -1.263988 & 0.6449348 & -1.96 & 0.050 & -2.528037 & 0.0000611 \\
\hline _Cons & 7.826786 & 0.8179467 & 9.57 & 0.000 & 6.22364 & 9.429932 \\
\hline Number of obs. & 1,856 & & & & & \\
\hline Number of groups & 111 & & & & & \\
\hline \multicolumn{7}{|l|}{ Obs. per group } \\
\hline Minimum & 1 & & & & & \\
\hline Average & 19.28987 & & & & & \\
\hline Maximum & 26 & & & & & \\
\hline Wald $\chi^{2}(31)$ & 708.80 & & & & & \\
\hline Prob $>\chi^{2}$ & 0.0000 & & & & & \\
\hline \multicolumn{7}{|l|}{ Estimated } \\
\hline covariances & 111 & & & & & \\
\hline \multicolumn{7}{|l|}{ Estimated } \\
\hline autocorrelations & 0 & & & & & \\
\hline \multicolumn{7}{|l|}{ Estimated } \\
\hline coefficients & 32 & & & & & \\
\hline Log-likelihood & -4.913 .651 & & & & & \\
\hline
\end{tabular}

Notes: Cross-sectional time-series FGLS regression. Coefficients: generalized least squares; panels: heteroskedastic; correlation: no autocorrelation. 
statistical methods borrowed from the epidemiology literature. Finally, in section 1.5.3, I provide some empirical results, obtained using econometric techniques, on the relationship between large current account deficits and financial crises. I argue that whether one finds a connection depends largely on three factors: (1) the definition of crisis, (2) the sample considered, and (3) the lag structure used in the analysis.

\subsubsection{Defining a Crisis}

Paul Krugman has recently said that "there is no generally accepted formal definition of a currency crisis, but we know them when we see them" (Krugman 2000, 1). While some authors, including myself in Edwards (1989) and Edwards and Santaella (1993), have defined a currency crisis as a very significant depreciation of the currency (see also Frankel and Rose 1996 and Milesi-Ferretti and Razin 2000) others have defined a crisis as a situation in which a country's currency is depreciated or its international reserves are seriously depleted (Eichengreen, Rose, and Wyplosz 1996; Goldstein, Kaminsky, and Reinhart 2000). In this paper, and in order to cast a very wide net in the empirical analysis, I have used two alternative criteria for defining crises.

The first definition follows Frankel and Rose (1996) and defines a currency crisis as a situation in which there is a currency depreciation of at least 25 percent as well as a 10 percent increase in the rate of depreciation. I call this variable aevent. ${ }^{21}$ The second definition is broader, and includes as crises situations in which the country in question has experienced a large depreciation or a significant loss in reserves. In constructing this variable, which I call acrisis, I followed a three-step procedure:

1. I created a weighted average index of monthly rate of change of the exchange rate $(\Delta e / e)$ and of reserves $(\Delta R / R)$, such that both components of the index have equal sample volatility: $I_{t}=\Delta e / e-\left(\sigma_{e} / \sigma_{R}\right) \cdot(\Delta R / R)$.

2. I define a crisis $\left(C_{t}\right)$ to have taken place when the index exceeds the mean of the index plus three standard deviations:

$$
C_{t}=\left\{\begin{array}{l}
1 \text { if } I_{t} \geq \text { mean }\left(I_{t}\right)+3 \sigma_{I} \\
0 \quad \text { otherwise }
\end{array}\right.
$$

3. I annualized the crisis index by considering each year as a June-June period. In other words, a year $t$ is assigned a crisis $(=1)$ if any month between June of year $t$ and June of year $t+1$ is a crisis.

As Milesi-Ferretti and Razin (2000) have pointed out, results from crisis analyses may be affected by the treatment of currency upheaval in consecutive years. In order to address this issue, I defined two additional crisis

21. The index was constructed on monthly data. In order to annualize it, I consider June-toJune years. 
Frequency of Crises: Alternative Indicators

\begin{tabular}{lrrr}
\hline & Frequency & Percent & Cumulative \\
\hline aevent: (mean) event & & & \\
0 & 2818 & 94.09 & 94.09 \\
1 & 177 & 5.91 & 100.00 \\
Total & 2995 & 100.00 & \\
aevent 2 & & & \\
0 & 2318 & 95.79 & 95.79 \\
1 & 102 & 4.21 & 100.00 \\
Total & 2420 & 100.00 & \\
acrisis: (mean) crisis & & & \\
0 & 2548 & 90.26 & 90.26 \\
1 & 275 & 9.74 & 100.00 \\
Total & 2823 & 100.00 & \\
acrisis 2 & & & \\
0 & 1564 & 88.91 & 88.91 \\
1 & 195 & 11.09 & 100.00 \\
Total & 1759 & 100.00 & \\
\hline
\end{tabular}

Source: Author's calculations.

Note: See the text for the exact definition of these indicators.

indicators that exclude adjacent "crises." These indicators consider a threeyear window after each crisis: aevent 2 is the three-year window corresponding to aevent, and acrisis2 is the corresponding indicator for acrisis.

How frequent have currency crises taken place, according to these indicators? This question is addressed in table 1.12, where I present tabulations for the four indexes for the complete sample. As may be seen, the frequency of "crises" goes from 4 percent to 11 percent of the country-year observations. In terms of the distribution across regions (the results are not presented in detail due to space considerations) according to both aevent indicators, crises have had a higher frequency in Eastern Europe; the lowest frequency is in the industrialized nations, with no crises recorded. The acrisis index records a frequency at approximately 10 percent in Latin America, Asia, and Africa; the acrisis 2 index shows that the highest frequency of crises has been in Africa, with a 13.7 percent frequency of occurrence.

\subsubsection{Current Account Reversals and Crises: A Preliminary Analysis}

An important finding from the preceding analysis is that current account reversals are common and quite frequent. Countries in every region tend to run deficits that occasionally exceed their long-run sustainable level. This means that, as documented above, at some point the country must go through an adjustment process in which the current account deficit is reversed and moves closer to its long-run equilibrium. From a policy perspective, it is important to understand whether current account reversals are related to currency crises. In order to address this issue, I followed a 
case-control methodology. ${ }^{22}$ This approach consists of using a $\chi^{2}$ statistic to formally test whether there is a significant relationship between a particular outcome (the case) and another variable to which both case and control variables have been exposed. The first step in applying this approach, then, is to separate observations into a case group and a control group. A country that for a given year experienced a "crisis" is considered to be a case, and noncrisis observations constitute the control group. The second step consists of calculating how many observations in both the case and control groups have been subject to a current account reversal. From this information an odds ratio is computed, and a $\chi^{2}$ test is computed in order to determine whether the odds ratio is significantly different from 1 . If the null hypothesis cannot be rejected, then there is evidence supporting the hypothesis that countries that are subject to a reversal have a significant probability of experiencing a crisis.

The computation of the $\chi^{2}$ test statistic using contemporaneous values of crisis and reversals results in the rejection of the null hypothesis that reversal countries are associated with a crisis. This result holds for all four definitions of a crisis. The $p$-values of the $\chi^{2}$ tests are on the order of 0.6 , or higher. This result is consistent with the conclusions reached through a less formal analysis, and using a smaller data set, by Milesi-Ferretti and Razin (2000).

A possible limitation of a simple application of this $\chi^{2}$ test, however, is that from a theoretical point of view the relationship between reversals and crises implies complex timing and causality issues. In fact, there are reasons to believe that reversals may occur at the same time as a crisis, before a crisis, or even after a crisis. For instance, the reversal may be so pronounced that the country in question has no alternative but to devalue its currency or deplete its international reserves. There is no reason, however, why these phenomena would take place at exactly the same time. Also, the reversal may be the result, rather than the cause, of a devaluation. For this reason, I also asked whether there is statistical evidence that there is a current account reversal in the "neighborhood" of a crisis. In order to do this, I define a new variable, reversaln, that takes a value of one on the year a reversal was detected, as well as in the previous and next years. The results from this second test suggest that it is not possible to reject the null hypothesis that currency crises occur "in the neighborhood of" current account reversals. This is the case for any of the four crisis definitions used in this study. In table 1.13 I present the results obtained from the computation of these $\chi^{2}$ statistics when the aevent definition of crisis was considered as the "case." In order to illustrate the nature of the results I have presented the $\chi^{2}$ corresponding to two definitions of reversals. In part A I used the narrow one-year definition of reversal, while in part B I use the broader three-year neighborhood definition of reversal. As may be seen, although in part A the $\chi^{2}$ test is not sig-

22. This approach is used frequently by epidemiologists. I became interested in the statistical techniques used by epidemiologists while doing research on financial crisis contagion across countries (see Edwards 2000). See Fleiss (1981) for details on the actual case-control method. 
Table 1.13

Case-Control $\chi^{2}$ Test: Analysis of Crisis and Current Account Reversals (for Aevent definition of crisis)

\begin{tabular}{|c|c|c|c|c|}
\hline & Exposed & Unexposed & Total & $\begin{array}{c}\text { Proportion } \\
\text { Exposed }\end{array}$ \\
\hline \multicolumn{5}{|c|}{ A. Exposed: Reversall definition of current account reversal ${ }^{\text {a }}$} \\
\hline Cases & 28 & 124 & 152 & 0.1842 \\
\hline Controls & 410 & 1,793 & 2,203 & 0.1861 \\
\hline \multirow[t]{2}{*}{ Total } & 438 & 1,917 & 2,355 & 1.1860 \\
\hline & \multicolumn{2}{|c|}{ Point Estimate } & \multicolumn{2}{|c|}{$95 \%$ Conf. Interval } \\
\hline \multirow{4}{*}{$\begin{array}{l}\text { Odds ratio } \\
\quad \text { (Cornfield) } \\
\text { Prev. frac. ex. } \\
\text { (Cornfield) } \\
\text { Prev. frac. pop }\end{array}$} & \multicolumn{2}{|c|}{0.9874902} & 0.6481554 & 1.504718 \\
\hline & \multicolumn{2}{|c|}{0.0125098} & -0.504718 & 03518446 \\
\hline & \multicolumn{2}{|c|}{0.0023282} & & \\
\hline & Exposed & Unexposed & Total & $\begin{array}{c}\text { Proportion } \\
\text { Exposed }\end{array}$ \\
\hline \multicolumn{5}{|c|}{ B. Exposed: Reversaln1 definition of current account reversal ${ }^{\mathrm{b}}$} \\
\hline Cases & 52 & 35 & 87 & 0.5977 \\
\hline Controls & 563 & 679 & 1,242 & 0.4533 \\
\hline \multirow[t]{2}{*}{ Total } & 615 & 714 & 1,329 & 0.4628 \\
\hline & \multicolumn{2}{|c|}{ Point Estimate } & \multicolumn{2}{|c|}{$95 \%$ Conf. Interval } \\
\hline \multicolumn{5}{|l|}{ Odds ratio } \\
\hline \multicolumn{5}{|l|}{ Attr. frac. ex. } \\
\hline (Cornfield) & & & 0.1335086 & 0.6405185 \\
\hline Attr. frac. pop. & & & & \\
\hline
\end{tabular}

Source: Computed by the author.

Note: Prev. $=$ previous; frac. $=$ fraction; ex. $=$ explained; pop. $=$ population; attr. $=$ attributed. ${ }^{\mathrm{a}} \chi^{2}(1)=0.00 ;$ Prob. $>\chi^{2}=0.9536$.

${ }^{b} \chi^{2}(1)=6.82 ;$ Prob. $>\chi^{2}=0.0090$.

nificant, in part B it is highly significant - the $p$-value is $0.009 .{ }^{23}$ Results obtained for the other three definitions of a crisis are very similar and are available from the author on request.

\subsubsection{Current Account Deficits and Currency Crises: A Formal Analysis}

In a recent and influential paper, Frankel and Rose (1996) empirically analyzed the determinants of currency crashes. Their data set included 105 countries for the period 1970-91, and their definition of a crisis was confined to devaluations in excess of 25 percent. ${ }^{24}$ The results from their probit

23. These results, however, should be interpreted with caution, as they are subject to all the limitations of this type of case-control analysis, including the fact that no causality can be established. In this case, however, I am not particularly interested in causation.

24. See section 1.5.1 for a discussion of their definition. 
regression analysis indicated that a number of variables were good predictors of a currency crash. These included the fraction of the debt obtained in concessional terms, the ratio of foreign direct investment (FDI) to GDP, the reserves-to-imports ratio, the rate of growth of domestic credit, the country's rate of growth, and international interest rates. In terms of the present paper, what is particularly interesting is that in Frankel and Rose (1996) the current account deficit was not significant, and in many of the regressions it even had the wrong sign. This led the authors to conclude that, "curiously, neither current account nor government budget deficits appear to play an important role in a typical crash" (365). ${ }^{25}$

My own initial analysis of the determinants of crises, using an almost identical data set, supports the results reported by Frankel and Rose (1996). When a broad sample and their regressors are used, the current account seems to play no role in major currency crashes. ${ }^{26}$ This is the case independently of the estimation technique used, and of whether the actual value of the current account deficit or a dummy for high deficits is included as a regressor. To my surprise, the incorporation of an independent variable that interacted the fiscal and current account deficits (the "twin" deficits) did not change the result.

In order to investigate this issue further, and in an effort to determine the robustness of these results, I followed four avenues of analysis: First, I inquired whether the results would hold under alternative data sets. In particular, I investigated whether the exclusion of particular regions would alter the finding of current account "irrelevance." Second, I considered alternative sets of independent variables in the estimation of probit equations for crises. In particular I considered alternative lag structures, and I included some variables that capture the economic structure of the countries in the sample. Third, I considered alternative definitions of crisis. More specifically, I estimated a number of probit equations for all four definitions of crisis described in subsection 1.5.1 of this paper: aevent, aevent2, acrisis, and acrisis2. Fourth, I used different estimation techniques and considered assumptions regarding the nature of the error term, including the assumption that it takes a random effect form. Generally speaking, the results obtained were not affected by the technique used, and for this reason I only report the basic results.

In the estimation of crisis models I used the following regressors: ${ }^{27}$ (1) percentage of debt in commercial terms; (2) percentage of debt in concessional terms; (3) percentage of debt at variable rate; (4) percentage of short-term debt; (5) FDI; (6) public-sector debt as percentage of GDP; (7) debt to the multilateral institutions; (8) the ratio of (gross) international reserves to imports; (9) the ratio of foreign debt to GDP; (10) the rate of

25. This finding is not affected by any of the sensitivity tests undertaken by the authors.

26. By "broad sample" I mean one that includes all regions in the world.

27. Most, but not all, of these regressors were used by Frankel and Rose (1996). The results reported here are not directly comparable to those of Frankel and Rose (1996), since the data sets are somewhat different. 
growth of domestic credit; (11) deviations of the real exchange rate from PPP (a measure of "overvaluation"); (12) the rate of growth of GDP; (13) the degree of openness of the economy, measured as imports plus exports divided by GDP; (14) the ratio of government expenditure to GDP; (15) interest rates in the advanced countries; and (16) the current account deficit. All the variables are from the World Bank and, as in the Frankel and Rose (1996) paper, cover the 1971-92 period. With the exception of the crisis indexes, trade openness, and government consumption, these variables correspond to those used by Frankel and Rose (1996).

In reporting the regressions, I follow the tradition of presenting the effects of a unitary change in the independent variables on the probability of a crisis. In all of the regressions I report White's robust standard errors that correct for heteroskedasticity.

The results obtained when all variables are entered contemporaneously and all regions are included are presented in table 1.14. The results are quite interesting and, to a large extent, in agreement with expectations. In terms of the current account - the variable of greatest interest in this paper - the results show significant differences, depending on the definition of crisis used. For both the acrisis and acrisis 2 indicators, the estimated coefficient of the current account deficit to GDP is positive and significant at the 10 percent level. On the other hand, when the aevent and aevent 2 currency crash indicators are used as the dependent variable, the estimated coefficients of the current account deficits are not significant, and in the case of aevent 2 , the sign is incorrect (although it is not significantly different from zero). Of course, the results for the events correspond to the Frankel and Rose (1996) findings discussed above. In terms of the other regressors, the results in table 1.14 suggest that higher reserves and higher growth reduce the probability of both types of crisis. Large FDI plays a particularly important role in reducing the probability of an event type of crisis. A high percentage of debt in commercial terms increases the probability of both types of crisis. A greater degree of openness reduces the probability under all crisis definitions. Notice that in contrast with the Frankel and Rose (1996) results, a higher public deficit ratio significantly increases the probability of aevent-type crises.

The results presented in table 1.14 were obtained using a data set that covers every region. There are, however, important reasons to believe that (most) African countries have behaved differently during the period under study. This is the case for two reasons: First, during the complete period under analysis a large number of African nations belonged to the CFA currency zone and were institutionally shielded from devaluations. Second, it is well known that during most of this period even non-CFA African nations had a great reluctance to adjust their parity. This was the case even when the external imbalance was very large (World Bank 1994). An important question, then, is how these results will be affected if the African nations are excluded from the sample. This is done in table 1.15, where probit 


\begin{tabular}{|c|c|c|c|c|c|c|c|}
\hline Definition & $\mathrm{dF} / \mathrm{dx}$ & $\begin{array}{l}\text { Robust } \\
\text { Std. Err. }\end{array}$ & $z$ & $P>|z|$ & $x$-bar & \multicolumn{2}{|c|}{$95 \%$ Conf. Interval } \\
\hline \multicolumn{8}{|c|}{$A$. acrisis Definition } \\
\hline COMRAT & 0.0033323 & 0.0017217 & 1.90 & 0.057 & 21.0027 & -0.000042 & 0.006707 \\
\hline CONRAT & -0.0010057 & 0.0007642 & -1.30 & 0.193 & 32.5979 & -0.002504 & 0.000492 \\
\hline VARRAT & -0.0025776 & 0.0016872 & -1.51 & 0.131 & 21.9735 & -0.005884 & 0.000729 \\
\hline FDISTOCK & 0.0052372 & 0.0022728 & -2.27 & 0.023 & 2.62669 & -0.009692 & 0.000783 \\
\hline SHORTTOT & 0.0019636 & 0.0015704 & 1.27 & 0.203 & 14.6745 & -0.001114 & 0.005041 \\
\hline PUBRAT & 0.0009573 & 0.0010942 & 0.88 & 0.381 & 72.419 & -0.001187 & 0.003102 \\
\hline MULTIRAT & 0.0020735 & 0.0008301 & 2.44 & 0.015 & 21.4711 & 0.000447 & 0.0037 \\
\hline DEBTY & 0.0002462 & 0.0002104 & 1.16 & 0.247 & 59.5954 & -0.000166 & 0.000659 \\
\hline RESERVEM & -0.0000357 & 0.0000375 & -0.94 & 0.345 & 324.331 & -0.000109 & 0.000038 \\
\hline DEFRAT & 0.0011096 & 0.0016363 & 0.68 & 0.497 & 5.15325 & -0.002097 & 0.004317 \\
\hline DLCRED & 0.0010474 & 0.0003367 & 3.23 & 0.001 & 21.875 & 0.000387 & 0.001707 \\
\hline DLY & -0.0027143 & 0.0013687 & -2.00 & 0.046 & 3.51322 & -0.005397 & 0.000032 \\
\hline ISTAR & 0.0020625 & 0.0030204 & 0.68 & 0.497 & 8.64066 & -0.003857 & 0.007982 \\
\hline OVERVALN & 0.0001934 & 0.0004058 & 0.48 & 0.634 & -7.88634 & -0.000602 & 0.000989 \\
\hline TRADE & -0.0009073 & 0.0005028 & -1.74 & 0.082 & 46.3937 & -0.001893 & 0.000078 \\
\hline GOVCON & -0.0001539 & 0.0017092 & -0.09 & 0.928 & 14.0511 & -0.003504 & 0.003196 \\
\hline CAD & 0.0031167 & 0.0016689 & 1.83 & 0.067 & 4.36866 & -0.000154 & 0.006388 \\
\hline obs. $P$ & 0.1031149 & & & & & & \\
\hline pred. $P$ & 0.0773022 & (at $\mathrm{x}$-bar) & & & & & \\
\hline Number of obs. & 931 & & & & & & \\
\hline Wald $\chi^{2}(17)$ & 56.70 & & & & & & \\
\hline Prob $>x^{2}$ & 0.0000 & & & & & & \\
\hline Pseudo $R^{2}$ & 0.1103 & & & & & & \\
\hline Log-likelihood & -274.9083 & & & & & & \\
\hline \multicolumn{8}{|c|}{$B$. acrisis 2 Definition } \\
\hline COMRAT & 0.0046036 & 0.0026754 & 1.65 & 0.100 & 19.9146 & -0.00064 & 0.009847 \\
\hline CONRAT & -0.0012766 & 0.0010286 & -1.24 & 0.213 & 34.1878 & -0.003293 & 0.000739 \\
\hline VARRAT & -0.0044843 & 0.0025206 & -1.71 & 0.086 & 21.1016 & -0.009425 & 0.000456 \\
\hline FDISTOCK & -0.0046245 & 0.0028175 & -1.65 & 0.099 & 3.12262 & -0.010147 & 0.000898 \\
\hline SHORTTOT & 0.0014552 & 0.0020551 & 0.71 & 0.479 & 14.7062 & -0.002573 & 0.005483 \\
\hline PUBRAT & -0.0001517 & 0.0014676 & -0.10 & 0.918 & 72.5714 & -0.003028 & 0.002725 \\
\hline MULTIRAT & 0.003031 & 0.0010866 & 2.66 & 0.008 & 21.5175 & 0.000901 & 0.005161 \\
\hline DEBTY & 0.0002802 & 0.0003342 & 0.83 & 0.404 & 54.2499 & -0.000375 & 0.000935 \\
\hline RESERVEM & -0.0000196 & 0.0000514 & -0.38 & 0.703 & 328.907 & -0.00012 & 0.000081 \\
\hline DEFRAT & 0.0020843 & 0.002524 & 0.82 & 0.410 & 4.60205 & -0.002863 & 0.007031 \\
\hline DLCRED & 0.0020764 & 0.0005264 & 4.02 & 0.000 & 18.7089 & 0.001045 & 0.003108 \\
\hline DLY & -0.002937 & 0.0019957 & -1.48 & 0.140 & 3.97093 & -0.006849 & 0.000975 \\
\hline ISTAR & 0.0052748 & 0.0038629 & 1.36 & 0.173 & 8.50495 & -0.002296 & 0.012846 \\
\hline OVERVALN & 0.0005167 & 0.000559 & 0.91 & 0.361 & -8.22226 & -0.000579 & 0.001612 \\
\hline TRADE & -0.0008263 & 0.0006416 & -1.28 & 0.201 & 47.0451 & -0.002084 & 0.000431 \\
\hline GOVCON & 0.0016096 & 0.002514 & 0.65 & 0.518 & 13.8002 & -0.003318 & 0.006537 \\
\hline CAD & 0.0039213 & 0.0023943 & 1.61 & 0.107 & 3.95843 & -0.000771 & 0.008614 \\
\hline obs. $P$ & 0.1209964 & & & & & & \\
\hline pred. $P$ & 0.0854189 & (at $x$-bar) & & & & & \\
\hline Number of obs. & 562 & & & & & & \\
\hline Wald $\chi^{2}(17)$ & 56.69 & & & & & & \\
\hline Prob $>\chi^{2}$ & 0.0000 & & & & & & \\
\hline Pseudo $R^{2}$ & 0.1387 & & & & & & \\
\hline Log-likelihood & -178.57014 & & & & & & \\
\hline
\end{tabular}




\begin{tabular}{|c|c|c|c|c|c|c|c|}
\hline Definition & $\mathrm{dF} / \mathrm{dx}$ & $\begin{array}{l}\text { Robust } \\
\text { Std. Err. }\end{array}$ & $z$ & $P>|z|$ & $x$-bar & \multicolumn{2}{|c|}{$95 \%$ Conf. Interval } \\
\hline \multicolumn{8}{|c|}{ C. aevent Definition } \\
\hline COMRAT & 0.0003686 & 0.0008709 & 0.42 & 0.671 & 20.962 & -0.001338 & 0.002075 \\
\hline CONRAT & -0.000823 & 0.0004234 & -1.82 & 0.069 & 32.6715 & -0.001653 & $6.9 \mathrm{e}-06$ \\
\hline VARRAT & -0.0007301 & 0.0008421 & -0.86 & 0.388 & 21.9302 & -0.002381 & 0.000921 \\
\hline FDISTOCK & -0.0033417 & 0.0012196 & -2.69 & 0.007 & 2.62084 & -0.005732 & -0.000951 \\
\hline SHORTTOT & -0.0000499 & 0.0008731 & -0.06 & 0.955 & 14.6571 & -0.001761 & 0.001661 \\
\hline PUBRAT & -0.0001298 & 0.0006229 & -0.21 & 0.836 & 72.4703 & -0.001351 & 0.001091 \\
\hline MULTIRAT & -0.0002948 & 0.0005312 & -0.56 & 0.578 & 21.4961 & -0.001336 & 0.000746 \\
\hline DEBTY & 0.0002863 & 0.0001209 & 2.49 & 0.013 & 59.7336 & 0.000049 & 0.000523 \\
\hline RESERVEM & -0.0000194 & 0.0000197 & -1.01 & 0.315 & 325.061 & -0.000058 & 0.000019 \\
\hline DEFRAT & 0.0016828 & 0.0009088 & 1.85 & 0.065 & 5.21531 & -0.000098 & 0.003464 \\
\hline DLCRED & 0.0004128 & 0.0002005 & 2.53 & 0.012 & 21.8889 & 0.000026 & 0.000812 \\
\hline DLY & -0.001096 & 0.0008227 & -1.34 & 0.179 & 3.51907 & -0.002708 & 0.000516 \\
\hline ISTAR & -0.0000236 & 0.0017433 & -0.01 & 0.989 & 8.63804 & -0.00344 & 0.003393 \\
\hline OVERVALN & -0.0003881 & 0.0002363 & -1.64 & 0.102 & -7.82043 & -0.000851 & 0.000075 \\
\hline TRADE & -0.001114 & 0.0003071 & -3.06 & 0.002 & 46.3682 & -0.001716 & -0.000512 \\
\hline GOVCON & -0.0037107 & 0.0012011 & -2.97 & 0.003 & 14.071 & -0.006065 & -0.001357 \\
\hline CAD & 0.0003098 & 0.0010221 & 0.30 & 0.764 & 4.37692 & -0.001693 & 0.002313 \\
\hline obs. $P$ & 0.0706638 & & & & & & \\
\hline pred. $P$ & 0.0296255 & (at $x$-bar) & & & & & \\
\hline Number of obs. & 934 & & & & & & \\
\hline Wald $\chi^{2}(17)$ & 70.66 & & & & & & \\
\hline Prob $>\chi^{2}$ & 0.0000 & & & & & & \\
\hline Pseudo $R^{2}$ & 0.2072 & & & & & & \\
\hline Log-likelihood & -189.0942 & & & & & & \\
\hline \multicolumn{8}{|c|}{ D. aevent 2 Definition } \\
\hline COMRAT & -0.000135 & 0.0009079 & -0.15 & 0.883 & 19.8866 & -0.001914 & 0.001644 \\
\hline CONRAT & -0.0003336 & 0.000392 & -0.85 & 0.395 & 35.0182 & -0.001102 & 0.000435 \\
\hline VARRAT & $7.77 \mathrm{e}-06$ & 0.0008146 & 0.01 & 0.992 & 20.4507 & -0.001589 & 0.001604 \\
\hline FDISTOCK & -0.0015405 & 0.0009866 & -1.62 & 0.104 & 3.08108 & -0.003474 & 0.000393 \\
\hline SHORTTOT & 0.0005935 & 0.0007601 & 0.81 & 0.416 & 14.3259 & -0.000896 & 0.002083 \\
\hline PUBRAT & 0.000125 & 0.0005304 & 0.24 & 0.810 & 72.7421 & -0.000914 & 0.001164 \\
\hline MULTIRAT & -0.0004797 & 0.0005018 & -0.94 & 0.349 & 22.8628 & -0.001463 & 0.000504 \\
\hline DEBTY & 0.0002004 & 0.0001292 & 1.62 & 0.105 & 54.0278 & -0.000053 & 0.000454 \\
\hline RESERVEM & -0.0000252 & 0.0000191 & -1.38 & 0.166 & 328.073 & -0.000063 & 0.000012 \\
\hline DEFRAT & 0.0022043 & 0.0010298 & 2.11 & 0.035 & 4.93033 & 0.000186 & 0.004223 \\
\hline DLCRED & 0.0005069 & 0.000229 & 2.74 & 0.006 & 18.4827 & 0.000058 & 0.000956 \\
\hline DLY & -0.0015771 & 0.0008004 & -1.90 & 0.057 & 4.18559 & -0.003146 & $-8.3 e-06$ \\
\hline ISTAR & 0.0000685 & 0.0014788 & 0.05 & 0.963 & 8.62569 & -0.00283 & 0.002967 \\
\hline OVERVALN & -0.0001668 & 0.0002045 & -0.84 & 0.402 & -7.73555 & -0.000568 & 0.000234 \\
\hline TRADE & -0.0007145 & 0.0002938 & -2.41 & 0.016 & 48.7758 & -0.00129 & -0.000139 \\
\hline GOVCON & -0.0028422 & 0.001161 & -2.20 & 0.028 & 14.5617 & -0.005118 & -0.000567 \\
\hline CAD & -0.0007552 & 0.0009831 & -0.79 & 0.432 & 4.27947 & -0.002682 & 0.001172 \\
\hline obs. $P$ & 0.0555556 & & & & & & \\
\hline pred. $P$ & 0.0206342 & (at $x$-bar) & & & & & \\
\hline Number of obs. & 702 & & & & & & \\
\hline Wald $\chi^{2}(17)$ & 48.97 & & & & & & \\
\hline Prob $>\chi^{2}$ & 0.0001 & & & & & & \\
\hline Pseudo $R^{2}$ & 0.2208 & & & & & & \\
\hline Log-likelihood & -117.36778 & & & & & & \\
\hline
\end{tabular}

Notes: Probit estimates. The tests that the underlying coefficient is 0 are $z$ and $P>|z|$. 


\begin{tabular}{|c|c|c|c|c|c|c|c|}
\hline Definition & $\mathrm{dF} / \mathrm{dx}$ & $\begin{array}{l}\text { Robust } \\
\text { Std. Err. }\end{array}$ & $z$ & $P>|z|$ & $x$-bar & \multicolumn{2}{|c|}{$95 \%$ Conf. Interval } \\
\hline \multicolumn{8}{|c|}{$A$. acrisis Definition } \\
\hline COMRAT & 0.0029271 & 0.0020359 & 1.42 & 0.157 & 26.3123 & -0.001063 & 0.006917 \\
\hline CONRAT & -0.0012155 & 0.0008973 & -1.32 & 0.186 & 28.4099 & -0.002974 & 0.000543 \\
\hline VARRAT & -0.0020405 & 0.0019753 & -1.02 & 0.306 & 27.1534 & -0.005912 & 0.001831 \\
\hline FDISTOCK & -0.005784 & 0.0024845 & -2.24 & 0.025 & 3.17666 & -0.010653 & 0.000915 \\
\hline SHORTTOT & 0.0016729 & 0.002148 & 0.81 & 0.418 & 15.9367 & -0.002537 & 0.005883 \\
\hline PUBRAT & 0.0014678 & 0.0013265 & 1.13 & 0.258 & 69.9099 & -0.001132 & 0.004068 \\
\hline MULTIRAT & 0.0026282 & 0.000894 & 2.77 & 0.006 & 19.8038 & 0.000876 & 0.00438 \\
\hline DEBTY & $3.91 \mathrm{e}-06$ & 0.0003489 & 0.01 & 0.991 & 53.1143 & -0.00068 & 0.000688 \\
\hline RESERVEM & $-7.38 \mathrm{e}-06$ & 0.0000403 & -0.18 & 0.855 & 412.658 & -0.000086 & 0.000072 \\
\hline DEFRAT & 0.0010166 & 0.0019793 & 0.52 & 0.606 & 4.5621 & -0.002863 & 0.004896 \\
\hline DLCRED & 0.0008556 & 0.0003243 & 2.85 & 0.004 & 25.8435 & 0.00022 & 0.001491 \\
\hline DLY & -0.0021348 & 0.0017565 & -1.24 & 0.215 & 3.8471 & -0.005577 & 0.001308 \\
\hline ISTAR & 0.0026776 & 0.0036062 & 0.73 & 0.466 & 8.48895 & -0.00439 & 0.009746 \\
\hline OVERVALN & -0.0000309 & 0.0005285 & -0.06 & 0.953 & -5.23607 & -0.001067 & 0.001005 \\
\hline TRADE & -0.0010877 & 0.0006823 & -1.48 & 0.140 & 47.171 & -0.002425 & 0.00025 \\
\hline GOVCON & 0.0017909 & 0.0023691 & 0.76 & 0.448 & 13.3222 & -0.002852 & 0.006434 \\
\hline CAD & 0.0048408 & 0.0021958 & 2.08 & 0.037 & 3.62618 & 0.000537 & 0.009145 \\
\hline obs. $P$ & 0.1075085 & & & & & & \\
\hline pred. $P$ & 0.0718758 & (at $x$-bar) & & & & & \\
\hline Number of obs. & 586 & & & & & & \\
\hline Wald $\chi^{2}(17)$ & 47.59 & & & & & & \\
\hline Prob $>\chi^{2}$ & 0.0001 & & & & & & \\
\hline Pseudo $R^{2}$ & 0.1381 & & & & & & \\
\hline Log-likelihood & -172.36345 & & & & & & \\
\hline \multicolumn{8}{|c|}{ B. acrisis2 Definition } \\
\hline COMRAT & 0.004239 & 0.0031281 & 1.27 & 0.203 & 25.0805 & -0.001892 & 0.01037 \\
\hline CONRAT & -0.0013723 & 0.0013069 & -1.08 & 0.279 & 30.3854 & -0.003934 & 0.001189 \\
\hline VARRAT & -0.0049427 & 0.0028411 & -1.67 & 0.095 & 26.3258 & -0.010511 & 0.000626 \\
\hline FDISTOCK & -0.0015863 & 0.0024665 & -0.65 & 0.515 & 3.68785 & -0.006421 & 0.003248 \\
\hline SHORTTOT & 0.001403 & 0.0024508 & 0.57 & 0.569 & 16.3144 & -0.003401 & 0.006207 \\
\hline PUBRAT & -0.0001419 & 0.001806 & -0.08 & 0.937 & 69.3619 & -0.003682 & 0.003398 \\
\hline MULTIRAT & 0.003184 & 0.0011121 & 2.54 & 0.011 & 19.659 & 0.001004 & 0.005364 \\
\hline DEBTY & 0.0001755 & 0.0006922 & 0.25 & 0.800 & 47.3123 & -0.001181 & 0.001532 \\
\hline RESERVEM & 0.0000193 & 0.0000523 & 0.37 & 0.709 & 418.177 & -0.000083 & 0.000122 \\
\hline DEFRAT & 0.0015161 & 0.0030651 & 0.49 & 0.625 & 3.85896 & -0.004491 & 0.007524 \\
\hline DLCRED & 0.0016191 & 0.0005431 & 3.02 & 0.003 & 22.0399 & 0.000555 & 0.002684 \\
\hline DLY & -0.0028787 & 0.0026685 & -1.12 & 0.261 & 4.74403 & -0.008109 & 0.002352 \\
\hline ISTAR & 0.0047575 & 0.0043004 & 1.12 & 0.264 & 8.25318 & -0.003671 & 0.013186 \\
\hline OVERVALN & 0.004106 & 0.0006962 & 0.59 & 0.555 & -3.96003 & -0.000954 & 0.001775 \\
\hline TRADE & -0.0019974 & 0.0007404 & -2.51 & 0.012 & 48.4653 & -0.003448 & -0.000546 \\
\hline GOVCON & 0.0074273 & 0.0029808 & 2.69 & 0.007 & 12.9495 & 0.001585 & 0.01327 \\
\hline CAD & 0.0066269 & 0.0030252 & 2.15 & 0.032 & 2.94552 & 0.000698 & 0.012556 \\
\hline obs. $P$ & 0.1232092 & & & & & & \\
\hline pred. $P$ & 0.0684454 & (at $x$-bar) & & & & & \\
\hline Number of obs. & 349 & & & & & & \\
\hline Wald $\chi^{2}(17)$ & 56.33 & & & & & & \\
\hline Prob $>x^{2}$ & 0.0000 & & & & & & \\
\hline Pseudo $R^{2}$ & 0.2104 & & & & & & \\
\hline Log-likelihood & -102.86684 & & & & & & \\
\hline
\end{tabular}




\begin{tabular}{|c|c|c|c|c|c|c|c|}
\hline Definition & $\mathrm{dF} / \mathrm{dx}$ & $\begin{array}{l}\text { Robust } \\
\text { Std. Err. }\end{array}$ & $z$ & $P>|z|$ & $x$-bar & \multicolumn{2}{|c|}{$95 \%$ Conf. Interval } \\
\hline \multicolumn{8}{|c|}{ C. aevent Definition } \\
\hline COMRAT & 0.0005594 & 0.0009588 & 0.58 & 0.561 & 26.2654 & -0.00132 & 0.002439 \\
\hline CONRAT & -0.0004993 & 0.0005171 & -0.89 & 0.373 & 28.4811 & -0.001513 & 0.000514 \\
\hline VARRAT & -0.0002586 & 0.000949 & -0.27 & 0.787 & 27.1044 & -0.002119 & 0.001601 \\
\hline FDISTOCK & -0.0029753 & 0.0012766 & -2.27 & 0.023 & 3.16641 & -0.005477 & 0.000473 \\
\hline SHORTTOT & 0.0009613 & 0.0011325 & 0.91 & 0.363 & 15.9162 & -0.001258 & 0.003181 \\
\hline PUBRAT & 0.0012306 & 0.0008209 & 1.71 & 0.086 & 69.9671 & -0.000378 & 0.00284 \\
\hline MULTIRAT & -0.0006806 & 0.0006162 & -1.21 & 0.227 & 19.7912 & -0.001888 & 0.000527 \\
\hline DEBTY & 0.0000792 & 0.0001567 & 0.51 & 0.613 & 53.3316 & -0.000228 & 0.000386 \\
\hline RESERVEM & -0.0000334 & 0.0000222 & -1.57 & 0.115 & 412.677 & -0.000077 & 0.00001 \\
\hline DEFRAT & 0.0011607 & 0.0009477 & 1.19 & 0.233 & 4.61603 & -0.000697 & 0.003018 \\
\hline DLCRED & 0.0002325 & 0.0001554 & 1.85 & 0.064 & 25.8675 & -0.000072 & 0.000537 \\
\hline DLY & -0.0015439 & 0.0009927 & -1.73 & 0.084 & 3.85051 & -0.003489 & 0.000402 \\
\hline ISTAR & 0.0001112 & 0.0019632 & 0.06 & 0.955 & 8.4883 & -0.003737 & 0.003959 \\
\hline OVERVALN & -0.0003815 & 0.0002373 & -1.49 & 0.137 & -5.18871 & -0.000847 & 0.000084 \\
\hline TRADE & -0.0010118 & 0.0003537 & -2.52 & 0.012 & 47.1363 & -0.001705 & 0.000318 \\
\hline GOVCON & -0.0021182 & 0.0012636 & -1.57 & 0.116 & 13.35 & -0.004595 & 0.000358 \\
\hline CAD & 0.0018845 & 0.0011319 & 1.62 & 0.105 & 3.64741 & -0.000334 & 0.004103 \\
\hline obs. $P$ & 0.0748299 & & & & & & \\
\hline pred. $P$ & 0.0253162 & (at $x$-bar) & & & & & \\
\hline Number of obs. & 588 & & & & & & \\
\hline Wald $\chi^{2}(17)$ & 64.52 & & & & & & \\
\hline Prob $>\chi^{2}$ & 0.0000 & & & & & & \\
\hline Pseudo $R^{2}$ & 0.2262 & & & & & & \\
\hline Log-likelihood & -121.01338 & & & & & & \\
\hline \multicolumn{8}{|c|}{ D. aevent 2 Definition } \\
\hline COMRAT & -0.000477 & 0.0006752 & -0.72 & 0.472 & 24.5388 & -0.0018 & 0.000846 \\
\hline CONRAT & -0.0001558 & 0.0003666 & -0.41 & 0.680 & 31.8778 & -0.000874 & 0.000563 \\
\hline VARRAT & 0.0003588 & 0.0006383 & 0.57 & 0.569 & 24.764 & -0.000892 & 0.00161 \\
\hline FDISTOCK & -0.0011275 & 0.0007419 & -1.46 & 0.145 & 3.82585 & -0.002582 & 0.000327 \\
\hline SHORTTOT & 0.0000871 & 0.0007133 & 0.12 & 0.901 & 15.8634 & -0.001311 & 0.001485 \\
\hline PUBRAT & 0.0002927 & 0.0005123 & 0.63 & 0.529 & 69.6303 & -0.000711 & 0.001297 \\
\hline MULTIRAT & -0.0011583 & 0.0005954 & -2.48 & 0.013 & 21.8597 & -0.002325 & $8.6 \mathrm{e}-06$ \\
\hline DEBTY & 0.0001485 & 0.000146 & 1.05 & 0.295 & 45.5271 & -0.000138 & 0.000435 \\
\hline RESERVEM & -0.000016 & 0.0000162 & -1.10 & 0.271 & 427.66 & -0.000048 & 0.000016 \\
\hline DEFRAT & 0.000573 & 0.0007951 & 0.71 & 0.476 & 4.27868 & -0.000985 & 0.002131 \\
\hline DLCRED & 0.0000761 & 0.000141 & 0.61 & 0.541 & 21.1944 & -0.0002 & 0.000353 \\
\hline DLY & -0.0013861 & 0.0008992 & -1.99 & 0.046 & 4.62599 & -0.003148 & 0.000376 \\
\hline ISTAR & -0.0002626 & 0.0011823 & -0.22 & 0.823 & 8.3681 & -0.00258 & 0.002055 \\
\hline OVERVALN & -0.0003454 & 0.0001643 & -2.03 & 0.042 & -4.5647 & -0.000667 & -0.000023 \\
\hline TRADE & -0.0008508 & 0.0003236 & -3.50 & 0.000 & 50.8592 & -0.001485 & -0.000217 \\
\hline GOVCON & -0.0004142 & 0.0008319 & -0.48 & 0.630 & 13.843 & -0.002045 & 0.001216 \\
\hline CAD & 0.001496 & 0.0009603 & 1.62 & 0.105 & 3.12759 & -0.000386 & 0.003378 \\
\hline obs. $P$ & 0.0636792 & & & & & & \\
\hline pred. $P$ & 0.01217 & (at $x$-bar) & & & & & \\
\hline Number of obs. & 424 & & & & & & \\
\hline Wald $\chi^{2}(17)$ & 44.63 & & & & & & \\
\hline Prob $>\chi^{2}$ & 0.0003 & & & & & & \\
\hline Pseudo $R^{2}$ & 0.2642 & & & & & & \\
\hline Log-likelihood & -73.926915 & & & & & & \\
\hline
\end{tabular}

Notes: Probit estimates. The tests that the underlying coefficient is 0 are $z$ and $P>|z|$. 
regressions for our four crisis definitions are presented for a non-Africa sample. As may be seen, when this is done, the estimated coefficient of the current account deficit is positive and significant either at the 5 or 10 percent level. It is important to notice that what makes a difference here is whether Africa is included in the sample. If instead of focusing on Africa I use GDP per capita as the key variable to split the sample, as Milesi-Ferretti and Razin (2000) do, and I include only middle-income countries, the results are not as distinct as those reported in table 1.15.

The results presented above follow Frankel and Rose (1996) and control for a number of variables, including the external debt ratio, capital flows in the form of FDI, and international reserves. A problem with including this group of controls, however, is that it becomes difficult to interpret the current account coefficient in the probit regressions. The reason for this is that we are not allowing the current account deficit to be financed through the traditional channels: an increase in indebtness or a reduction in international reserves. In fact, in the results reported above, as well as in Frankel and Rose (1996), higher account deficits are being financed exclusively by an increase in non-debt-generating capital inflows. It is interesting to understand, however, if an increase in the current account deficit that is financed by running up the debt or depleting international reserves increases the probability of a crisis. The results in table 1.16, which were obtained when both reserves and debt are not included as controls, show that an increase in the current account deficit financed by traditional means indeed increases the probability of an aevent type of crisis. ${ }^{28}$

As a final exercise, and in order to analyze the robustness of these results, I investigated whether they held under different lag structures for the regressors. In particular I considered the following structure: all debt variables were entered contemporaneously, as were the structural variables, and the country performance and policy variables were entered with a oneperiod lag. The results obtained indicate that when this alternative lag structure is used, the coefficient of the current account deficit remains positive and significant at conventional levels. When every regressor is entered with one lag, the coefficient of the current account deficit remains positive and significant. In that case, however, some of the debt variables became nonsignificant.

To sum up, the results presented in this section suggest that the effects of larger current account deficits on crisis depend on both the definition of a crisis and on the regions of the world being covered. More specifically, the results indicate that when the broader definitions acrisis and acrisis2 are used, a higher current account deficit increases the probability of crisis in the larger sample. Higher current account deficits also increase the proba-

28. The results for an acrisis type of crisis are similar and are not reported here due to space considerations. 


\begin{tabular}{|c|c|c|c|c|c|c|c|}
\hline Aevent & $\mathrm{dF} / \mathrm{dx}$ & $\begin{array}{l}\text { Robust } \\
\text { Std. Err. }\end{array}$ & $z$ & $P>|z|$ & $x$-bar & \multicolumn{2}{|c|}{$95 \%$ Conf. Interval } \\
\hline COMRAT & -0.0000411 & 0.0008099 & -0.05 & 0.960 & 26.3022 & -0.001629 & 0.001546 \\
\hline CONRAT & -0.0005226 & 0.000528 & -0.93 & 0.354 & 28.4596 & -0.001557 & 0.000512 \\
\hline VARRAT & 0.000294 & 0.000864 & 0.34 & 0.731 & 27.1331 & -0.001399 & 0.001988 \\
\hline FDISTOCK & -0.0034274 & 0.0013471 & -2.52 & 0.012 & 3.15382 & -0.006068 & -0.000787 \\
\hline SHORTTOT & 0.0009178 & 0.0011867 & 0.81 & 0.417 & 15.9153 & -0.001408 & 0.003244 \\
\hline PUBRAT & 0.0012746 & 0.0008641 & 1.65 & 0.099 & 70.0393 & -0.000419 & 0.002968 \\
\hline MULTIRAT & -0.0007383 & 0.0006296 & -1.27 & 0.202 & 19.7436 & -0.001972 & 0.000496 \\
\hline DEFRAT & 0.017021 & 0.000881 & 1.85 & 0.064 & 4.68826 & -0.000025 & 0.003429 \\
\hline DLCRED & 0.0002103 & 0.0001511 & 1.66 & 0.096 & 26.0009 & -0.000086 & 0.000506 \\
\hline DLY & -0.0018491 & 0.0010946 & -1.87 & 0.062 & 3.83729 & -0.003995 & 0.000296 \\
\hline ISTAR & 0.0003013 & 0.0020829 & 0.14 & 0.885 & 8.48095 & -0.003781 & 0.004384 \\
\hline OVERVALN & -0.000391 & 0.0002352 & -1.52 & 0.128 & -5.48445 & -0.000852 & 0.00007 \\
\hline TRADE & -0.0010849 & 0.0003564 & -2.56 & 0.011 & 47.1491 & -0.001783 & -0.000386 \\
\hline GOVCON & -0.0019375 & 0.0012981 & -1.43 & 0.153 & 13.455 & -0.004482 & 0.000607 \\
\hline CAD & 0.0024955 & 0.001186 & 2.09 & 0.037 & 3.71074 & 0.000171 & 0.00482 \\
\hline obs. $P$ & 0.0761421 & & & & & & \\
\hline pred. $P$ & 0.0279486 & (at $x$-bar) & & & & & \\
\hline Number of obs. & 591 & & & & & & \\
\hline Wald $\chi^{2}(17)$ & 65.13 & & & & & & \\
\hline Prob $>\chi^{2}$ & 0.0000 & & & & & & \\
\hline Pseudo $R^{2}$ & 0.2198 & & & & & & \\
\hline Log-likelihood & -124.15434 & & & & & & \\
\hline
\end{tabular}

Notes: Excludes reserves and debt. Probit estimates. The tests that the underlying coefficient is 0 are $z$ and $P>|z|$.

bility of aevent crises significantly when the African nations are excluded from the sample.

\subsection{Concluding Remarks}

The main question addressed in this paper is whether the current account "matters." If this question is interpreted very narrowly, in the sense that countries with an arbitrarily defined large current account deficit almost inevitably face a crisis, then the answer is no. If, however, it is interpreted more broadly, as suggesting that there are costs involved in running very large deficits, the research reported in this paper suggests that the answer is a qualified yes. ${ }^{29}$

29. Naturally, a major challenge in this work is defining what a "large" deficit means. In theory, "large" should mean "significantly larger than the sustainable level." In practice, however, and as is shown in section 1.3 of this paper, existing sustainability models are not very useful, especially in a dynamic environment. For this reason, in this paper I have defined a "high deficit" arbitrarily, as a deficit that for that year exceeds the 3rd quartile of the deficit distribution for the region to which the country belongs. 
The analysis presented in this paper has shown that large current account deficits tend not to be persistent. Very few countries run large deficits for five years in a row, and only a handful have run large deficits for ten years in a row. As the analysis in section 1.4 of this paper suggests, the typical pattern of current account deficits is that countries that experience large imbalances do so for a limited time; after a while, these imbalances are reduced, and a current account reversal is observed. In section 1.4 I analyzed in detail the consequences, in terms of economic performance, of current account reversals using a large (unbalanced) panel of countries for 197097. Using recently developed econometric techniques, I found that, contrary to what has been recently suggested, reversals do have a negative effect on economic performance. They negatively affect aggregate investment; moreover, even when I control for investment, the regression analysis suggests that reversals have a negative impact on GDP growth per capita.

In section $1.5 \mathrm{I}$ addressed the narrower question of whether larger deficits increase the probability of a country experiencing a currency crisis. My results suggest that the answer to this question depends on the definition of a crisis as well as on the sample used in the analysis. As the detailed explanation in that section indicates, my results show that when Africa is excluded - and I argue that there are good reasons for doing so - an increase in the deficit raises the probability of a crisis, independently of how this term is defined. When the complete sample is used, higher deficits increase the probability of broadly defined crises. They have no statistical effect on narrowly defined crashes, however.

In sum, my conclusion is that, in spite of recent claims of the irrelevance of current account deficits, the evidence provides rather strong support for the view that, from a policy perspective, large deficits should be a cause for concern. This does not mean, of course, that every large deficit leads to a crisis; nor does it mean that only when there is a large current account deficit can a crisis take place.

\section{References}

Ades, Alberto, and Federico Kaune. 1997. A new measure of current account sustainability for developing countries. New York: Goldman Sachs Emerging Markets Economic Research.

Arellano, Manuel, and Stephen Bond. 1991. Estimation of dynamic models with error components. Journal of the American Statistical Association 76:245-67.

Atkeson, Andrew, and Jose-Victor Rios-Rull. 1996. The balance of payments and borrowing constraints: An alternative view of the Mexican crisis. Federal Reserve Bank of Minneapolis Staff Report no. 212.

Attanasio, Orazio P., Lucio Picci, and Antonello E. Scorcu. 2000. Saving, growth, and investment: A macroeconomic analysis using a panel of countries. Review of Economics and Statistics 82 (2): 182-211. 
Bacchetta, Philippe, and Eric van Wincoop. 2000. Trade in nominal assets and net international capital flows. Journal of International Money and Finance 19 (1): 66-91.

Bank of Mexico. The Mexican Economy, various issues. Mexico City: Bank of Mexico.

Barro, Robert J., and Xavier Sala-i-Martin. 1995. Economic Growth. Cambridge: MIT Press.

Beck, Nathaniel, and Jonathan N. Katz. 1995. What to do (and not to do) with timeseries cross-section data. American Political Science Review 89 (3): 124-47.

Blanchard, Olivier. 1983. Debt and the current account deficit in Brazil. In Financial policies and the world capital market: The problem of Latin American countries, ed. Pedro Aspe-Armella, Rudiger Dornbusch, and Maurice Obstfeld, 95-109. Chicago: University of Chicago Press.

Bruno, Michael. 1995. Currency crises and collapses: Comment. Brookings Papers on Economic Activity, Issue no. 2:278-85.

Calvo, Guillermo A. 2000. Balance of payments crises in emerging markets: Large capital inflows and sovereign governments. In Currency crises, ed. Paul Krugman, 3-28. Chicago: University of Chicago Press.

Calvo, Guillermo A., Leonardo Leiderman, and Carmen Reinhart. 1993. Capital inflows and real exchange rate appreciation in Latin America: The role of external factors. IMF Staff Papers 40 (March): 868-907.

Chang, Roberto, and Andres Velasco. 2000. Exchange-rate policy for developing countries. American Economic Review 90 (2): 71-75.

Chase Manhattan Bank. 1997. Emerging markets after Thailand: Guilt by association or flattered by comparison? Unpublished report, October 1.

Cline, William R. 1988. International debt: Progress and strategy. Finance and Development 25 (2): 9-11.

Cooper, Richard N. 1971a. Currency devaluation in developing countries. Princeton Studies in International Finance no. 86. Princeton University, Department of Economics, International Economics Section.

. 1971b. Issues for trade policy in the seventies. Tübingen, Germany: Mohr.

Corden, W. Max. 1994. Economic policy, exchange rates, and the international system. Oxford: Oxford University Press.

Corsetti, Giancarlo, Paolo Pesenti, and Nouriel Roubini. 1998. Paper tigers? A model of the Asian crisis. Paper presented at the NBER-Bank of Portugal International Seminar on Macroeconomics. 14-15 June, Lisbon, Portugal.

Deutsche Bank. 2000. Global market research. New York: Deutsche Bank. March.

Dornbusch, Rudiger. 2000. Keys to prosperity: Free markets, sound money, and a bit of luck. Cambridge: MIT Press.

Edwards, Sebastian. 1989. Structural adjustment policies in highly indebted countries. In Developing country debt and economic performance vol. 2, ed. Jeffrey D. Sachs, 234-67. Chicago: University of Chicago Press.

. 1993. Exchange rates as nominal anchors. Weltwirtschaftliches Archiv 129: $1-33$.

1996. Why are Latin America's savings rates so low? An international comparative analysis. Journal of Development Economics 51 (1): 5-44.

1999. On crisis prevention: Lessons from Mexico and East Asia. In Financial markets and development, ed. Alison Harwood, Robert E. Litan, and Michael Pomerleano, 269-334. Washington, D.C.: Brookings Institution.

2000. Contagion. The World Economy 23 (7): 873-900.

Edwards, Sebastian, and Alejandra Edwards. 1991. Monetarism and liberalization: The Chilean experience. Chicago: University of Chicago Press.

Edwards, Sebastian, and Julio Santaella. 1993. Devaluation controversies in the developing countries: Lessons from the Bretton Woods era. In A retrospective on the 
Bretton Woods System: Lessons for international monetary reform, ed. Michael D. Bordo and Barry J. Eichengreen, 405-60. Chicago: University of Chicago Press.

Edwards, Sebastian, and Sweder van-Wijnbergen. 1986. The welfare effects of trade and capital market liberalization. International Economic Review 27 (1): 325-41.

Eichengreen, Barry, Andrew K. Rose, and Charles Wyplosz. 1996. Contagious currency crises. NBER Working Paper no. 5681. Cambridge, Mass.: National Bureau of Economic Research, April.

Fernandez de Cordoba, Gonzalo, and Timothy J. Kehoe. 2000. Capital flows and real exchange rate fluctuations following Spain's entry into the European Community. Journal of International Economics 51 (1): 128-51.

Fischer, Stanley. 1988. Real balances, the exchange rate, and indexation: Real variables in disinflation. Quarterly Journal of Economics 103 (1): 27-49.

-1994. Comments on Dornbusch and Werner. Brookings Papers on Economic Activity, Issue no. 1:304-09.

Fleiss, J. L. 1981. Statistical methods for rates and proportions. New York: John Wiley and Sons.

Frankel, Jeffrey A., and Andrew Rose. 1996. Currency crashes in emerging markets: An empirical treatment. Journal of International Economics 41 (November): 351-66.

Frenkel, Jacob A., and Assaf Razin. 1987. Fiscal policies and the world economy: An intertemporal approach. Cambridge: MIT Press.

Ghosh, Atish R., and Jonathan D. Ostry. 1995. The current account in developing countries: A perspective from the consumption-smoothing approach. World Bank Economic Review 9: 45-67.

Goldstein, Morris, Graciela L. Kaminsky, and Carmen R. Reinhart. 2000. Assessing financial vulnerability: An early warning system for emerging markets. Washington, D.C.: Institute for International Economics.

Harberger, Arnold. 1950. Currency depreciation, income and the balance of trade. Journal of Political Economy 2 (February): 341-57.

Heckman, James J., Hidehiko Ichirmua, and Petra Todd. 1998. Matching as an econometric evaluation estimator. Review of Economic Studies 65 (2).

Johnson, Harry G. 1955. Economic expansion and international trade. Manchester School of Economic and Social Studies 23.

Kamin, Steven B. 1988. Devaluation, exchange controls, and black markets for foreign exchange in developing countries. Board of Governors of the Federal Reserve System, International Finance Discussion Paper no. 334. Washington, D.C.: Board of Governors of the Federal Reserve System.

Krugman, Paul. 2000. Currency crises. Chicago: University of Chicago Press.

Laursen, Svend, and Lloyd Metzler. 1950. Flexible exchange rates and the theory of employment. Review of Economics and Statistics 32.

Loayza, Norman, Klaus Schmidt-Hebbel, and Luis Servén. 2000. What drives private saving around the world? World Bank Development Research Group Working Paper no. 2309. Washington, D.C.: World Bank.

Loser, Claudio M., and Ewart S. Williams. 1997. The Mexican crisis and its aftermath: An IMF perspective. In Mexico 1994, ed. Sebastian Edwards and Moises Naim, 259-73. Washington, D.C.: Carnegie Endowment.

Machlup, Fritz. 1943. International trade and international income multiplier. Philadelphia: Blakiston.

Meade, James E. 1951. The balance of payments. London: Oxford University Press.

Milesi-Ferretti, Gian Maria, and Assaf Razin. 1996. Sustainability of persistent current account deficits. NBER Working Paper no. 5467. Cambridge, Mass.: National Bureau of Economic Research, September.

1998. Sharp reduction in current account deficits: An empirical analysis. European Economic Review 42:127-45. 
2000. Current account reversals and currency crises: Empirical regularities. In Currency crises, ed. Paul Krugman, 285-326. Chicago: University of Chicago Press.

Nerlove, Marc. 1971. Further evidence on the estimation of dynamic economic relations from a time series of cross-sections. Econometrica 39:359-82.

Obstfeld, Maurice, and Kenneth Rogoff. 1996. Foundations of international macroeconomics. Cambridge: MIT Press.

Radelet, Steven, and Jeffrey Sachs. 2000. The onset of the East Asian financial crisis. In Currency crises, ed. Paul Krugman, 105-58. Chicago: University of Chicago Press.

Razin, Assaf, and Lars E. O. Svensson. 1983. The current account and the optimal government debt. Journal of International Money and Finance 2 (2): 459-501.

Robichek, E. Walter. 1981. Some reflections about external public debt management. Estudios Monetarios VII: 139-49. Santiago, Chile: Banco Central de Chile.

Sachs, Jeffrey. 1981. The current account and macroeconomic adjustment in the 1970s. Brookings Papers on Economic Activity, Issue no. 1:201-68. Washington, D.C.: Brookings Institution.

Sachs, Jeffrey, Aaron Tornell, and Andrés Velasco. 1996. Financial crises in emerging markets: The lessons of 1995. Brookings Papers on Economic Activity, Issue no. 1:147-217. Washington, D.C.: Brookings Institution.

Salinas de Gortari, Carlos. 2000. Memorias. Madrid: Editorial Plaza y Janes.

Sheffrin, Steven M., and Wing Thye Woo. 1990. Testing an optimizing model of the current account via the consumption function. Journal of International Money and Finance 9 (2).

Summers, Lawrence H. 1996. Commentary. In Volatile capital flows, ed. Ricardo Hausmann and Liliana Rojas-Suarez, 17-25. Washington, D.C.: Inter-American Development Bank.

2000. International financial crises: Causes, prevention, and cures. American Economic Review 90 (2): 3-21.

World Bank. 1993. Trends in developing economies. World Bank. 1994. Trends in developing economies. World Bank.

\section{Comment Alejandro M. Werner}

This paper touches upon three issues. First, it comprehensively reviews the evolution of the academic and policy makers' views on the role of the current account during the last twenty-five years. Second, it goes over models of current account sustainability used in financial institutions to argue that, although these models provide certain information regarding sustainability, they are useless to determine whether, at a particular point in time, a country is running large current account deficits. Finally, the paper presents the results from a huge data set on

1. The distribution of current account deficits across time and across regions.

2. The channels though which sudden stops affect growth.

3. The relationship between current account deficits and financial crises.

Alejandro M. Werner is director of economic studies at Bank of Mexico. 
Let me say that I am sympathetic to the idea that current accounts matter, and that I think the evidence presented in this paper shows this to be the case and goes deeper into the channels through which this takes place. In my comments, I will concentrate on two issues: first, the empirical relevance of the sustainability model presented in the paper, and second, the relationship between current account reversals and crises.

\section{Models of Current Account Sustainability}

Given that the sustainable level of the current account should be determined by the willingness of the rest of the world to finance it, Edwards begins from standard portfolio theory and derives the net demand for a country's liabilities. This is a perfectly reasonable way to explain the determinants of the sustainable level for the current account deficit. However, to judge whether this model provides a sensible order of magnitude for the sustainable current account deficit in different countries, Edwards uses the results of a model developed by Goldman Sachs. He claims that,

Using a very similar framework to the one developed above, Goldman Sachs has made a serious effort to actually estimate long-run sustainable current account deficits for a number of countries (Ades and Kaune 1997). . . . [T] he estimated levels ... [range] from 1.9 to 4.5 percent of GDP.... [A]lthough the range for the "Short-Run Sustainable Level" is broader, in very few countries does it exceed 4 percent of GDP.

Although the Ades and Kaune model was also developed to calculate sustainable current account deficits, it is conceptually different from the model presented in Edwards's paper. In the Ades and Kaune model, the net international demand for a country's liabilities is not derived from a portfolio model. When calculating this net demand, Ades and Kaune take into account a country's incentives for defaulting on its debt. Therefore, the international net demand for a country's liabilities is determined by the maximum amount international capital markets can safely lend without triggering a default. Thus, the stock of a country's liabilities held by foreigners and the sustainable current account deficit will be determined by the equality between the benefit of defaulting (and suffering the penalty of losing access to the international capital market) and the benefit of maintaining access to the international capital market.

The literature that is closest to Edwards' derivation of the sustainable current account deficit and that should be used to test the relevance of this model is the one that tries to explain the equity home bias puzzle (see French and Poterba 1991; Tesar and Werner 1998; Lewis 1999). In this literature, the international investor chooses the proportion of his or her wealth that he or she wants to hold in domestic equity, and finds a demand for domestic stocks equivalent to equation (4) in Edwards's paper. When these models are confronted with the evidence, the degree of diversification implied by them is much larger than that observed in the real world. Ac- 
cording to Lewis $(1999,578)$, "Clearly no degree of risk intolerance can justify such a low level of foreign portfolio allocation. Thus, these numbers suggest the presence of home bias."

These results imply that the portfolio diversification model predicts a much larger demand for a country's liabilities than the one observed in practice. Thus, they also predict current account deficits larger than those observed in the real world. Therefore, in addition to the problems associated with the transitions related to changes in portfolio allocations, it seems that these models also have important shortcomings in their implications for the long-run sustainable level for the current account deficit.

\section{Empirical Issues}

With respect to the empirical section, I will like to complement the paper's results on the relationship between current account reversals and currency crises with the Mexican experience. In particular, the Mexican crisis of December 1994 clearly shows that the current account reversal took place after the collapse of the currency. This supports the results of the paper that show that the relationship between the current account and crises implies complex timing issues.

As is clear from figure 1C.1, in 1994 Mexico suffered a capital account

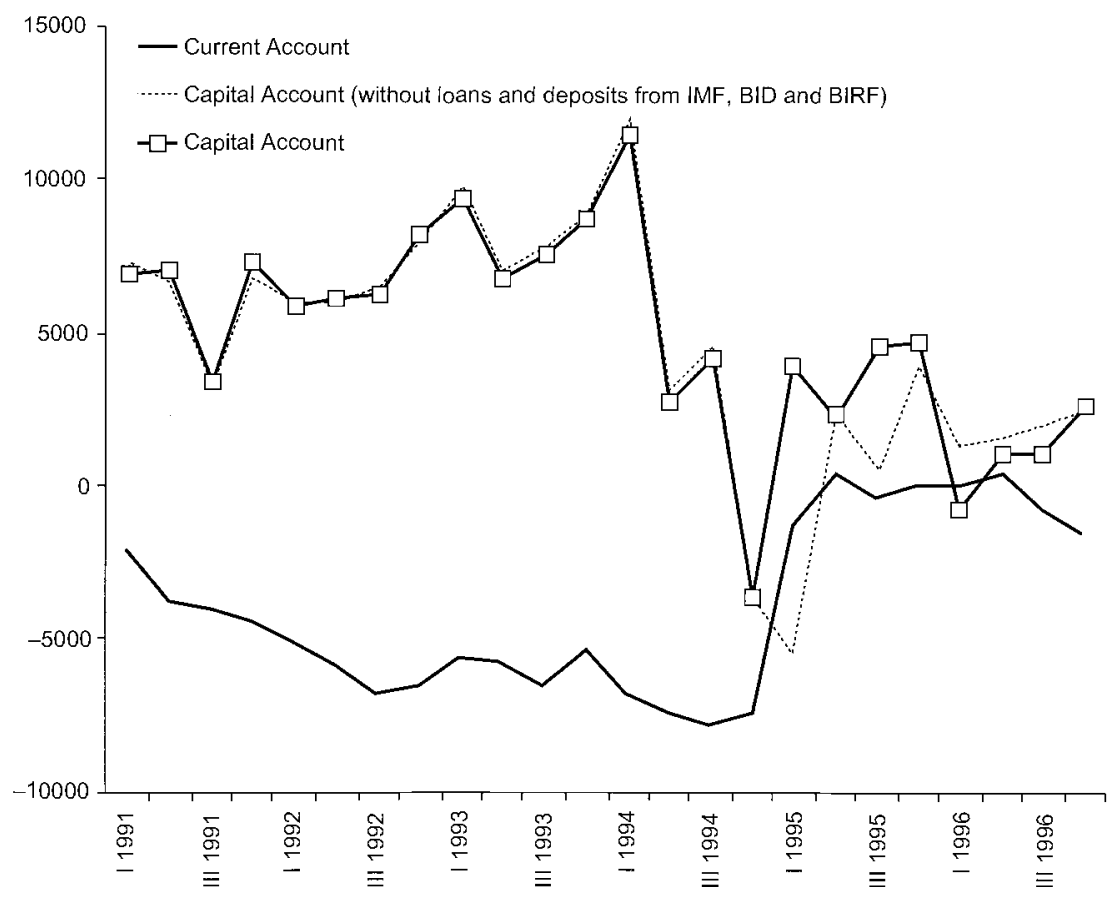

Fig. 1C.1 Current and capital account balance 


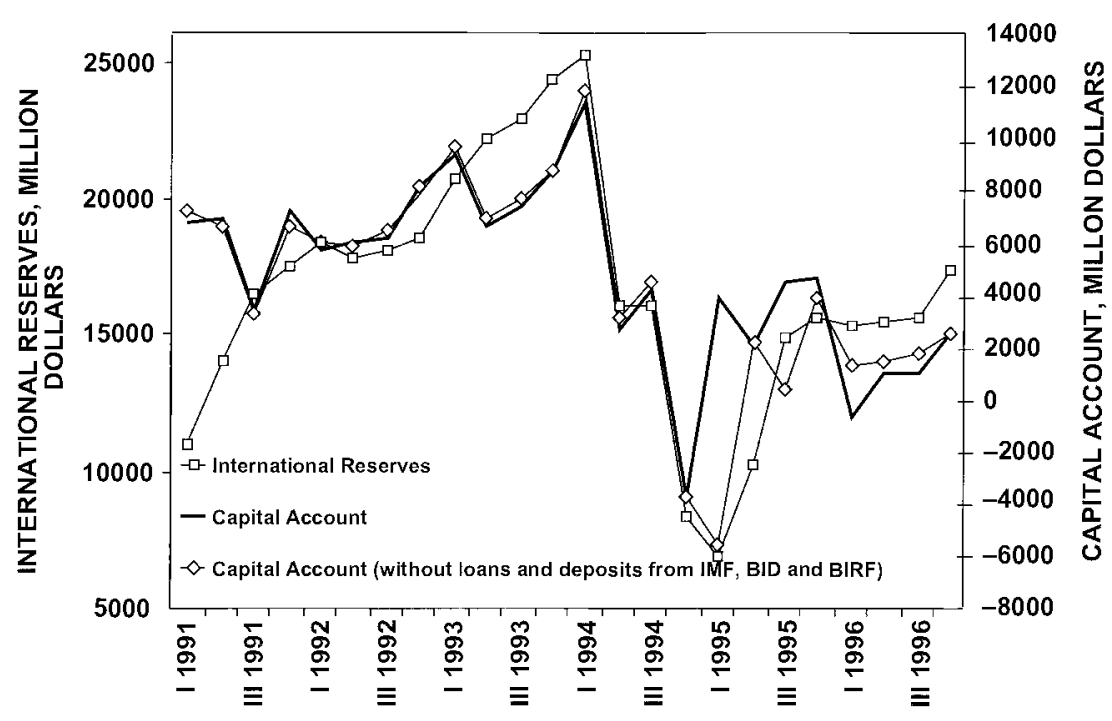

Fig. 1C.2 Capital account and international reserves

surplus reversal. In that year, the capital account balance went from a surplus of 11.4 billion dollars in the first quarter to -3.7 billion dollars in the fourth quarter. As shown in figure 1C.1, the current account deficit continued its downward trend during 1994. Obviously, domestic absorption was cushioned from the correction in the capital account surplus by the foreign reserve loses incurred by the central bank (see fig. 1C.2). Once reserves were depleted, the currency crisis ensued and the correction in the current account took place.

In conclusion, I think the paper is an important contribution to the literature and provides new and important evidence of the role that current account deficits play in currency crises, and the channels through which large current account reversals affect growth.

\section{References}

Ades, Alberto, and Federico Kaune. 1997. A new measure of current account sustainability for developing countries. Goldman Sachs Emerging Markets Economic Research. 29 September.

French, Kenneth R., and James M. Poterba. 1991. International diversification and international equity markets. American Economic Review 81 (2): 526-66.

Lewis, Karen. 1999. Trying to explain home bias in equities and consumption. Journal of Economic Literature 37:571-608.

Tesar, Linda, and Ingrid Werner. 1998. The internationalization of securities markets since the 1987 crash. In Brookings-Wharton papers on financial services, ed. Robert E. Litan and Anthony M. Santomero. Washington, D.C.: Brookings Institution. 


\section{Discussion Summary}

A few people made remarks on whether and why current accounts matter for predicting crises. According to Jeffrey A. Frankel, it is important to distinguish whether the current account deficit matters for causing currency crises or for other things, such as long-term growth. As far as crises are concerned, it is important to determine whether a current account deficit is a necessary or a sufficient condition, or, as the economic profession views it, whether there is a statistically significant relationship between current account deficits and crises. Frankel commended the author for emphasizing the difference between the isolated effect of the current account on crises (in a multivariate setting) and the effect in a univariate regression.

Frankel made a couple of additional comments, offering an insight on the history of thought regarding the Lawson fallacy. The statement attributed to Nigel Lawson is that the current account deficit is not a cause for concern if foreign borrowing goes to the private sector. Lawson later qualified this statement, pointing out that this is not to say that high current account deficits will never lead to a crisis. According to Frankel, this qualification is a weak "straw man." Frankel went on to comment on the paper's approach to identifying the impact of a sudden reversal of the current account on the output growth rate. He said that a sudden reversal is most likely to take the form of a reduction in investment. The author showed that, indeed, the sudden reversal of the current account affects the growth rate through this channel.

Anne O. Krueger discussed why and how the composition of a current account deficit matters. She emphasized that the correct distinction is not between public and private uses of foreign capital, but rather of how efficiently the money is spent. The former distinction is useless for a category as fungible as the current account. She brought up the example of Brazil: When Brazil increased its interest rates, the private sector responded by borrowing from abroad while the public sector borrowed domestically. Krueger questioned whether this made any difference. As for the matter of sustainability, she stressed that the important difference is between rapidly growing countries excess demand for investment, and countries that have very high investment rates in order to sustain some degree of growth without an increase of productivity. For example, Korea had 10 percent of current account deficit during its ten years of most rapid growth. She suggested that the author find variables to capture productivity in the study of current account. Later in the discussion, Jungho Yoo echoed Krueger's comment on how foreign savings (current account) are utilized.

Liliana Rojas-Suarez supported Krueger's point. She said that a current account should be understood as being on a sustainable path if the economy is generating trade balances that enable it to avoid an ever-increasing accu- 
mulation of net foreign liabilities without the need either to devalue or to adjust economic activity severely. In this regard, the quality of investment is extremely relevant. A current account deficit that is basically the result of highly productive investment is likely to be more sustainable than a current account deficit resulting from low saving. The reason is that highly productive investment increases the economy's production capacity. Higher future output, in turn, enables the economy to pay back its foreign liabilities. She said that, in general, funding the current account deficit with foreign direct investment tends to help sustainability because FDI tends to go to productive investment projects, especially on the tradable goods sector.

Relating to the discussion of how the quality of investments affects the sustainable debt level, Michael P. Dooley agreed that, historically, what countries do with the money seems to have been important. However, he added, the conclusion might be the opposite of that implicit in the previous paragraph: If defaulting on the external debt is a strategic decision, then the better a debtor uses the capital inflow, the more independent the debtor becomes, and the more likely it will default.

That for which the current account deficit matters was also discussed. Jorge Braga de Macedo suggested that the paper could broaden the scope, rather than limiting the discussion to emerging markets or adjustable pegs. For example, he said that current accounts still matter within the euro zone. Even if there will no longer be currency crises, there could still be debt or banking crises in the euro zone. Jaume Ventura pointed out that the question of how well current account deficits predict crises is different from the conventional approach to its welfare consequences. In (intertemporal) models of the current account, a large deficit has no welfare costs and does not ask for government intervention. Eduardo Borensztein commented on whether current account deficits could predict crises. He said that an IMF study focusing on emerging markets (twenty-seven countries) found that current account deficits are very significant predictors of crises. The somewhat weak result of the paper in this regard may suggest that the effects of current accounts differ across different groups of countries.

On the paper's treatment (exclusion) of African countries, Braga de Macedo disagreed with the author. He said that the devaluation in some African countries in 1994 showed that Africa is just like any other region, and that excluding these countries from the sample seemed unjustified. Frankel said that, in his paper with Andrew Rose, he and Rose found no significant relationship between current accounts and crises in univariate regressions. Edwards' finding of a significant correlation could be the result of excluding African countries from the sample. Dooley supported this point by citing his 1987 paper with Frankel and Don Mathieson, which found that non-market borrowers (those who depend primarily on official financing) have much larger and more persistent current account imbalances. This, he said, could explain why the Edwards paper found different 
results when dropping African countries. Krueger suggested the author could include African countries but exclude the official aid flows to the region.

Martin Feldstein commended the paper's emphasis on the transition between different optimal stock levels of foreign capital. He said that this emphasis was very important because countries easily confuse the temporary increase of capital flows as a result of a shift in the desired stock level with a sustainable higher level of current account flow, as in the case of Mexico.

Ventura commented on the idea of sustainability, saying that transversality conditions were introduced in the early models where the current account was assumed to equal domestic saving. In these models, checking sustainability simply means to confirm empirically, the transversality condition, which is a theoretical artifact. The approach of this paper, however, is different from that of the earlier literature in that the current accounts are a result of portfolio choices. Ventura questioned the meaning of sustainability in this new context.

Rudi Dornbusch said that the sudden-stop view would predict crises first and large current account reversals second. He suggested that the author look into this relationship.

Krueger also expressed concerns about the data on different forms of capital flows, such as equity and foreign direct investment. She said that the use of derivatives is most likely to blur the distinction among such categories.

Kristin J. Forbes asked what the author's view was on the (high) U.S. current account deficit.

Regarding that for which the current account matters, Edwards said that in the newer version of the paper, he had made it explicit. That is, large current account deficits do not unavoidably lead to catastrophic crises, but they do, with high degree of likelihood, result in large welfare losses. He said that the policy implication of the paper is very important. For example, there is a heated discussion on whether the Mexican current account deficit (about 4 percent) is too large. Should Mexico allow the exchange rate to depreciate to handle that deficit, or should it be left to float and possibly lead to a crisis? The concern of the paper is whether a large current account warrants a policy intervention.

A related question is when to "apply the break," as some countries (such as Chile) use large account deficits as targets for their monetary policies.

On the questions of the crowding out of foreign saving by domestic saving and on the use of saving, he said that the quality of investment could possibly be proxied by interacting the deficit and the competitiveness index from the World Economic Index.

Finally, on the current high level of the U.S. current account, Edwards said that no industrial country has had so high a level of current deficit in his data set, and that he believes this level is unsustainable. 
